\title{
Reflexões Sobre uma Sentença do Tribunal Constitucio- nal Chileno que Declara Inconstitucional a Normativa Que Permite o Uso da "Pílula do Dia Seguinte"
}

\author{
CONSIDERATIONS ABOUT THE DECISION OF THE \\ CONSTITUTIONAL COURT OF CHILE REGARDING \\ THE EMERGENCY CONTRACEPTION DRUG ("PLAN B")
}

Juan E. Blengio ${ }^{(* *)}$

\section{PRECISÕES}

A extensa sentença ditada em 18 de abril de 2008 pelo Tribunal Constitucional chileno(1), apresenta vários pontos de extraordinário interesse. Não é, entretanto, meu propósito considerá-los todos, mas fazer específica referência à chamada questão da "pílula do dia seguinte". Não somente porque é talvez o aspecto mais polêmico, mas porque permite colocar questões, como o direito à vida e o nascimento da pessoalidade, que são universais e, portanto, tornam viáveis reflexões e conclusões com uma amplitude que excede o marco de um direito positivo concreto.

É por isso também que dos argumentos invocados pela sentença e pelas divergências, assim como dos trazidos pelas partes, se fará referência - em regra - àqueles que se harmonizem com o enfoque universalista que se postula para este estudo.

Como assinalou-se, a questão é suscetível de uma variedade de enfoques, os quais, convém notar, incidem nas conclusões a que se pode chegar.

O primeiro e seguramente, na perspectiva deste estudo, especialmente transcendente, enquanto condiciona de alguma maneira os restantes, é o relativo ao conceito e ao alcance da interpretação e, mais especificamente, o da interpretação constitucional e a natureza da atuação do juiz.

(*) NOTA DO EDITOR: O autor reproduz diversos trechos da decisão, com 277 páginas, que está disponível em: <http://www.tribunalconstitucional.cl/index.php/sentencias/download/pdf/914>.

$\left({ }^{* *}\right)$ Professor de Direito Privado II e III (Obrigações e Contratos) da Facultad de Derecho de la Universidad de la República Oriental del Uruguay.E-mail: <mroque@chasque.net>.

Recebido em 03.02.09. Aprovado em 03.03.09. 
É naturalmente inviável no marco de um artigo como o presente, tentar abordar em profundidade a questão da natureza e alcance da interpretação e especialmente da interpretação constitucional. Por isso, me limitarei a fazer algumas breves, porém necessárias, reflexões.

Assim, por exemplo, para quem admite, seguindo Kelsen, que a interpretação é um processo intelectual que invariavelmente acompanha a tarefa de aplicação e criação em que constantemente se resolve todo ordenamento jurídico, que culmina em uma decisão (que no caso da sentença é um ato de vontade) mediante a qual se cria uma nova norma, ajustada ao marco da norma interpretada, seu conteúdo pode variar. Pois bastará que ele se adeque a algum dos significados possíveis da norma interpretada entre aqueles que podem ser eleitos livremente pelo legislador ou pelo juiz ${ }^{(2)}$.

A eleição não terá igual margem de discricionariedade na medida em que se entenda que os valores não são (como sustenta Kelsen) fatores situados fora do campo do direito, mas parte integrante dele. Porém, se desta perspectiva a liberdade do juiz aparece limitada, por outro lado, sua função criadora e as possibilidades de cumprir cabalmente sua missão específica - fazer justiça - , se veem fortalecidas pelas características e as funções que cumprem os valores e princípios, especialmente para quem admite seu caráter normativo e a aplicabilidade direta e indireta da Constituição às relações horizontais ${ }^{(3)}$.

(1) Ver FACULTAD de Derecho. Universidad de Chile. Disponible en: <www.derecho.uchile.cl/cej/ actulidad/otro/Sentencia_Constitucional\%20Sobre\%20la\%20Pildora\%20del\%20Dia..>. Otexto, nessa versão $P D F$, tem a inusual extensão de 277 páginas. Por isso que, para facilitar seu conhecimento, dedica-se um capítulo da presente nota de jurisprudência para sintetizá-lo, transcrevendo seus aspectos medulares. Desse modo, tendo em conta que esse julgado identifica com precisão tais questões e que os argumentos esgrimidos a favor e contra (pelos impugnantes, pela Presidência, pela maioria do Tribunal e pelos votos dissidentes), o leitor terá os elementos essenciais para chegar as suas próprias conclusões.

(2) KELSEN, Hans. Teoría pura del derecho. 5. ed. B. Aires: Eudeba, 1962, p. 163. Segundo esta teoria a natureza da atividade do juiz é criadora de direito e implica um ato de vontade, com margem de opção legítima que, no caso das normas constitucionais, é particularmente frouxo. Assim, os fatores morais, éticos e científicos serão simplesmente (alguns dos) argumentos que levarão em conta o legislador (e o Juiz) para optar legitimamente por uma entre várias soluções possíveis. Por outro lado, segundo a opinião largamente dominante no seio do positivismo clássico, e particularmente para os exegetas, o Juiz se limita a aplicar a lei; é meramente la bouche de la loi, pois, segundo esta visão, a interpretação conduz, infalivelmente, a uma só significação, que seria, além disso, a única aceitável.

(3) Assim, entre nós, Van ROMPAEY, Leslie. Reflexiones sobre los principios generales de derecho. Anuario de Derecho Civil Uruguayo, t. 30, p. 727 y ss., 2000 e Hacía una jurisprudencia principialista. Revista de Derecho de la Universidad Católica, v. 6, p. 169 ss., 2004 e BLENGIO, Juan La autonomía de la voluntad y sus límites. Su coordinación con el principio de igualdad. Anuario de Derecho Civil Uruguayo, t. 27, p. 395 y ss. 1997 y ss. Ver entre outros: VIGO, Rodolfo, VIGO, Rodolfo. Los principios jurídicos. Buenos Aires: Depalma, 2000. DWORKIN, Ronald. Interpretación constitucional. 2. ed. Buenos Aires: Ed. Lexis Nexis; Abeledo-Perrot, 2004. DWORKIN, Ronald. Los derechos en serio. Barcelona: Ariel, 1984. ALEXY, Robert. El concepto y la validez del derecho. 2. ed. Barcelona: Gedisa, 2004 y Tres escritos sobre los derechos fundamentales y la teoría de los principios. Bogotá: Universidad Externado de Colombia, 2003. 
Ao contrário, outra seria a solução em uma ótica mais restritiva, rigidamente positivista no sentido estrito e rígido do termo ${ }^{(4)}$, como a da chamada teoria da exegese na qual o eixo do sistema jurídico é a lei, esgotando-se o papel do Juiz ao aplicá-la mecanicamente, sem qualquer margem para a criação.

Para que o leitor possa ponderar o sentido e o alcance das reflexões que seguem, deve-se assinalar que, para o autor, a atividade jurisdicional, que implica interpretar e aplicar o direito, é uma tarefa criativa, que se traduz em um ato de vontade pelo qual o juiz, optando por uma das possíveis soluções que oferece o marco normativo, cria uma norma individual(5).

Entendo ainda que a Constituição é um sistema de valores que tem uma dimensão objetiva e que os princípios, como ensina Alexy, são mandados de otimização que tendem a se aplicar no maior grau jurídica e faticamente possível(6). Por isso, em caso de conflito entre eles, como ocorre na espécie, pode-se recorrer à teoria das margens de ação e à ponderação para resolvê-los ${ }^{(7)}$.

Convém também notar que considero que vigora a presunção de regularidade ou de legitimidade da lei(8). Portanto, o onus probandi de sua inconstitucionalidade caberá a quem alegue sua contrariedade com as normas e princípios constitucionais.

A quarta precisão é a de que o problema medular a resolver é o de determinar se certos fármacos ou procedimentos (Levonorgestro, e Yuzpe, DIU, aos quais se circunscrevem as reflexões que seguem) afetam o direito à vida. Para o que será preciso responder a três interrogações:

a) quais são os titulares do direito à vida;

b) quando existe uma pessoa; e

c) se tais fármacos ou procedimentos afetam o direito à vida das entidades individualizadas como pessoas.

(4) Kelsen é claramente positivista e, entretanto, como se verá, sustenta que a sentença é uma decisão que cria uma norma, ainda que a margem de possibilidades de escolha de seu conteúdo seja limitada no marco das significações identificadas da norma que se trata de aplicar.

(5) Convém notar que por exigência dos arts. 17 e 20 do CC nem todos os métodos interpretativos têm igual relevância, devendo-se dar primazia ao método lógico sistemático. Em consequência, o significado atribuído à norma como resultado da aplicação desse método deve primar sobre os outros possíveis, sem prejuízo de que, dado que os valores e os princípios são parte do sistema, será necessário considerar sua adequação a eles. Pode ocorrer, entretanto, que ao fim do trabalho interpretativo, não se chegue a um, mas a vários significados possíveis da norma interpretada. Isso ocorrerá, em geral, com as normas de amplo alcance, como é o caso das constitucionais.

(6) ALEXY, Robert. Tres escritos sobre los derechos fundamentales y la teoría de los principios, cit., p. 95 y ss.

(7) Id. Ibid., p. 62 y ss

(8) BLENGIO, Juan. op. cit. y ALEXY, Robert. El concepto y la validez del derecho, cit., p. 95. 
Outra importante precisão é a de que, uma vez esclarecidas as questões mencionadas, será necessário determinar se os atos que poderiam afetar o direito à vida não apontam ao mesmo tempo para a tutela de outros direitos e, em tal caso, ver como se resolve o conflito.

Em sexto lugar, quero assinalar que em nosso país [Uruguai] se promulgou a Lei $n$. 18426, de 10 de dezembro de 2008, que regula os direitos sexuais e reprodutivos. Em sua versão sancionada pelo Parlamento, incluía vários capítulos, com previsões que despenalizavam o aborto ainda quando tivesse sido decidido por uma mulher grávida, sem outra fundamentação que sua vontade, sempre que praticado dentro das doze primeiras semanas da gestação. Entretanto, tais capítulos, incluídas tais previsões, foram vetados pelo Presidente Vázquez e dado que não houve votos necessários na Assembleia Geral para rejeitá-lo, o veto foi mantido.

As razões que se invocaram para fazê-lo, como se verá, ainda que não contemplassem concretamente a situação da chamada pílula do dia seguinte, nem por isso deixavam de se aplicar à espécie, mesmo que não pareça ter sido esse um resultado buscado pelo exercício do veto. A observação é necessária, pois, em nosso país, o uso de tais fármacos é permitido e também porque o uso do DIU, em combinação com sua administração, é por certo frequente e é uma técnica que substancialmente envolve os mesmos problemas que a chamada pílula do dia seguinte.

Por último, é necessário apontar que não é possível, ao menos na atualidade (talvez nunca o tenha sido e dificilmente o será), resolver a questão tomando-a como uma pura questão jurídica, pois, estão envolvidos aspectos científicos, morais, éticos e filosóficos que têm um peso decisivo na adoção de uma solução.

Basta, para demonstrá-lo, ter presente como se valoriza a incidência de um fármaco que provoque ou possa provocar que um óvulo fecundado não se possa nidar, uma vez que tal valoração diferirá radicalmente segundo se considere ou não essa entidade uma pessoa e de acordo com a forma em que se resolva o conflito entre os direitos que lhe sejam reconhecidos com outros direitos, princípios e interesses (em particular os da mulher gestante e da sociedade).

É obvio notar que a questão resolvida pela sentença tem incidência em uma importante variedade de planos que não serão considerados agora, como os relativos à fecundação in vitro, à investigação e à disposição dos embriões em diversas situações ${ }^{(9)}$.

(9) Ver LANZIANO, Wáshington. El aborto y el derecho a la vida. Montevideo: FCU, 2003. p. 64 y ss. 


\section{A SENTENÇA QUE SE COMENTA}

\section{Introdução}

A sentença por suas características, pela extensa e circunstanciada fundamentação da decisão do Tribunal Constitucional do Chile, pela argumentação a que recorrem as partes e as razões invocadas pelos magistrados em divergência, não só tem a possibilidade de se converter em um leading case (no país transandino), mas permite também enfocar com caráter geral o modo de se colocar e resolver um problema que, como acontece nos países sul-americanos que penalizam o aborto, tem arestas espinhosas e de difícil solução.

Dado que a sentença é muito extensa, nas páginas que se seguem, a fim de facilitar ao leitor seu conhecimento sem perder a objetividade, será feita sua transcrição parcial de modo a sintetizar seus aspectos essenciais e especialmente aqueles que, por suas características, permitam (na medida do possível) extrapolar a questão julgada, seus diferentes enfoques e suas razões para além do marco do direito chileno. Em seguida, se fará uma análise da temática na perspectiva do direito uruguaio.

\section{A colocação da questão na sentença comentada}

O núcleo da questão analisada coloca-se essencialmente em uma passagem da sentença que faz referência às "razões dos demandantes da declaração de inconstitucionalidade".

Estes, diz a sentença ,"notam que a ação de inconstitucionalidade se dirige contra as disposições contidas nas "Normas Nacionais sobre Regulação da Fertilidade", que foram aprovadas e que são parte do Decreto Supremo N. 48, de vinte e seis de janeiro do ano dois mil e sete, do Ministério da Saúde, publicado no Diário Oficial em sua edição do dia três de fevereiro do mesmo ano.

Ditas normas são impugnadas, conforme assinalam os peticionários, só enquanto autorizam a distribuição e o uso da denominada "Pílula do Dia Seguinte", seja por meio da entrega de uma só pastilha de progestina pura, geralmente levonorgestro a 0,75 mg, ou por meio da combinação de pílulas, método denominado "Yuzpe", e "a utilização do dispositivo intrauterino (DIU)". "Este corresponde a uma (sic) das possibilidades da chamada anticoncepção apenas com progestágeno". Afirmam os requerentes que o mecanismo de ação dos métodos individualizados seria idêntico, pois produzem uma alteração endometrial que atua impedindo a nidação do indivíduo concebido e, desta perspectiva, indicam, seriam contrários ao preceituado nos arts. 5o, inciso segundo, $6^{\circ}, 7^{\circ}$ e 19 , ns. 1 e 26, da Carta Fundamental". 
Esclarecem que: "a aprovação de métodos e mecanismos que afetam a vida do que está por nascer importa de fato uma restrição a um direito fundamental garantido na Constituição de um modo por ela não autorizado". Além disso, "No caso sub lite, afirmam, se está frente a uma norma de valor regulamentar que foi emitida pela autoridade pública sem contar com norma legal habilitante para tanto e que, também, restringe substantivamente $o$ direito à vida garantido a todas as pessoas no art. 19, n. 1, da Constituição Política, dentro das quais se deve entender incluídas aquelas que estão por nascer, a quem o constituinte quis amparar de um modo particular. Tais fármacos e procedimentos, teriam "um efeito abortivo que seria contrário aos preceitos constitucionais".

\section{As razões invocadas pelos impugnantes}

Os Deputados peticionários insistem no estatuto jurídico aplicável ao embrião e, em particular nos seguintes aspectos:

1) "O art. 19, n. 1, inciso primeiro, da Carta Fundamental de 1980, consagra o direito à vida e à integridade física e psíquica das pessoas" e o inciso segundo do mesmo preceito se encarregou de reconhecer expressamente que "a lei protege a vida do que está por nascer", isto é, "a vida do embrião, nasciturus ou concepto e não nascido, conferindo-Ihe, portanto, a qualidade de sujeito de direito em nosso ordenamento jurídico."

2) Notam que complementa "a regulação constitucional referida precedentemente... a subscrição pelo Estado do Chile de pactos internacionais, como a Convenção Americana de Direitos Humanos ou Pacto de San José de Costa Rica, que em seu art. 4ํ, n. 1, assinala: "Toda pessoa tem direito a que se respeite sua vida. Este direito estará protegido pela lei e, em geral, a partir do momento da concepção. Ninguém pode ser privado da vida arbitrariamente".

3) "Igualmente, a Convenção dos Direitos da Criança, que se refere a estas matérias em seus artigos 1ㅇ, 3.2. e 6”".

4) $O$ art. 75 do Código do ramo dispõe a obrigação que pesa sobre os tribunais de dar proteção jurídica ao concepto e não nascido: "a lei protege a vida do que está por nascer. O juiz, em consequência, tomará, a pedido de qualquer pessoa ou de ofício, todas as providências que lhe pareçam convenientes para proteger a existência do não nascido, sempre que de algum modo haja risco". Por isso ... "ao reconhecê-lo como um sujeito digno de proteção jurídica, fica evidente que aponta para o direito à vida, e para a que este seja o único "patrimônio" que a esta altura tem o embrião humano." 
5) $\mathrm{O}$ art. 85 do Código Penal, que por derrogação da pena de morte perdeu eficácia jurídica, não teria perdido "o valor de persuasão moral" quando dispõe que "não se executará a pena de morte na mulher grávida, nem se Ihe notificará da sentença que lhe é imposta, até que tenham passado quarenta dias do parto".

6) Diversos "ditames emitidos pela Controladoria Geral da República, nos quais se reconheceu titularidade jurídica do concebido e não nascido, à luz do ordenamento jurídico nacional (ditame ns. 8 25.403, de 21 de agosto de 1995, e 14.525, de 15 de junho de 1992)".

7) Fazem presente, além disso, a existência de antecedentes que dão conta da maneira contraditória em que a autoridade do setor atuou no momento de analisar os efeitos que pode produzir a "pílula do dia seguinte" no embrião, com o que, advertem, "se produziria uma violação da doutrina dos atos próprios da Administração, que se vincula com a boa-fé que deve orientar a atuação de seus órgãos".

8) Se invoca o "principio pro vida", assinalando-se "que em todo Estado de Direito existe um princípio de ética pública que deve ser aplicado, principalmente quando é a autoridade pública a que age, no sentido seguinte: ante a possível dúvida sobre a ameaça de morte por utilização de uma droga, o Estado deve agir a favor da vida... é o órgão administrativo encarregado de aprovar um determinado produto farmacêutico ou procedimento anticonceptivo dentro de uma política pública, o que frente à menor dúvida quanto a se eles podem afetar a vida humana, deve se abster de agir... Criticam os peticionários, a seguir, o fato de que a autoridade sanitária não afirme "o efeito abortivo que têm estes métodos" e que ao mesmo tempo não o descarte, e que tal atitude, em seu entender, seria inconstitucional em si mesma. Insistem em notar, neste ponto, que "... o onus probandi recairá sempre em quem exerce a autoridade sanitária, que deverá acreditar que tais ou quais procedimentos não atentem contra a vida do concebido e não nascido, dado que nosso ordenamento jurídico defende a vida do que está por nascer, mandato constitucional dado ao legislador que se cumpre entre outras muitas disposições (sic) de nosso ordenamento jurídico com a seguinte (sic): 'Não se poderá executar qualquer ação cujo fim seja provocar o aborto' (Lei n. 18.826 Modificadora do Código Sanitário)".

9) $\mathrm{Na}$ mesma ordem de considerações, os requerentes julgam que não se deve esquecer que em matéria de Direitos Humanos rege o denominado "'principio pro-homine', o qual foi destacado reiteradamente pela Corte Interamericana de Direitos Humanos, v. g., na Opinião Consultiva 5/1985, e do qual se derivam dois parâmetros fundamentais em matéria de hermenêutica constitucional, a saber: I) Que se deve dar sempre a interpretação mais favorável ao direito ou liberdade do afetado e II) Que se deve dar sempre a interpretação mais favorável ao mais débil". 
10) Por outra parte, fazendo referência a "alguns dados científicos básicos" relacionados com o direito à vida do que está por nascer, "os requerentes notam que quando um espermatozoide fecunda um óvulo se forma um novo ser - um embrião. No começo este novo ser tem caráter unicelular, mas esta primeira célula conteria toda sua informação constitutiva. Nele se acharia o denominado 'código da vida' que a humanidade pôde decifrar há não muito tempo e que se encontra tanto nesse ser unicelular como em qualquer ser humano nascido, seja ele criança, jovem, adulto ou velho, homem ou mulher. Em suma, dizem, se aquela célula é o resultado da união de gametas humanos, é impossível, então, negar que se trata de um ser humano, pois é um ser e é humano, e pertence à espécie humana."

11) Discutem o "efeito eventualmente abortivo do Levonorgestro. Expõem que demonstrar que ele, administrado oralmente (pílula ou pílulas combinadas) ou por meio do Dispositivo Intrauterino (DIU), inclui um efeito antinidatório do ovo humano fecundado, não seria um assunto que ofereceria maior dificuldade".

Agregam que "se tal composto se administra em seguida a que o óvulo tenha sido fecundado não haveria ação anticonceptiva, posto que a concepção já se teria verificado. Por outro lado, assinalam que seria "próprio do mecanismo de ação do DIU que ele atue do modo mais eficaz impedindo a nidação e que sua destinação nunca tenha sido evitar a ovulação; pelo contrário as taxas de ovulação das usuárias do DIU são de 100\%”.

\section{Razões contra a demanda de inconstitucionalidade aduzidas pela Presidência}

1) Se ressalta que a "missão do Decreto Supremo n. 48, de 2007, foi continuar com a política de regulação da fertilidade iniciada em 1962 e que foi dirigida a "reduzir a alta incidência de abortos induzidos e suas complicações, e diminuir o alto custo associado a seu tratamento... fundada nos seguintes princípios: a) reduzir a taxa de mortalidade materna, relacionada em medida importante com o aborto provocado clandestino; b) reduzir a taxa de mortalidade infantil, relacionada com o deterioro do nível de vida em setores de população com alta fecundidade; e c) promover o bem-estar da família, favorecendo a procriação responsável".

Por outro lado "se trata de normas que têm um sólido substrato ético jurídico", sendo que o Ministério da Saúde, ... para a definição de suas políticas de regulação da fertilidade, reconhece que "para alcançar o ótimo estado de saúde, as pessoas e casais devem ter a possibilidade de se reproduzir com riscos mínimos, podendo regular sua fertilidade, decidir livremente se têm ou não filhos, quantos e quando, e desfrutar de uma sexualidade 
prazenteira e segura". Seguindo em tais considerações, a autoridade diz que "os serviços de regulação da fertilidade (...) estão centrados nas pessoas e em seus direitos mais que em metas populacionais ou políticas".

2) O "Princípio de autonomia e respeito pelas pessoas, supõe, ... apoiar as decisões livres das pessoas com respeito a sua sexualidade e reprodução", o que se "vincula aos direitos de cidadania, e responde a uma aspiração que se instala progressivamente na população de nosso país".

3) As normas impugnadas "respeitam a diversidade dos valores das pessoas, pois não pretendem impor um método anticonceptivo único, a anticoncepção de emergência não seria um ato impositivo do Estado, uma vez que: a) ela opera quando se tenha realizado um coito não protegido, por isso se denomina pílula do dia seguinte".

4) "Os estudos científicos que examinaram os mecanismos de ação da contracepção de emergência se concentraram em sua ação sobre a ovulação, sobre a fertilização e sobre a implantação, mas não sobre sua ação após a implantação".

O "debate central entre os científicos diz respeito à dúvida sobre se a "pílula do dia seguinte" afeta ou não a implantação do embrião. Tal controvérsia científica se deu, indica, porque uma série de investigações encontraram efeitos sobre a estrutura elou função do endométrio e outras, ao contrário, não os encontraram".

5) Se diz pela Presidência, baseado em diversos estudos, que "a comunidade científica concorda no fato de que não há técnicas que permitam comprovar a existência de gravidez antes da implantação".

6) O Executivo observa também que "a definição de gravidez da Organização Mundial da Saúde (OMS) seria reflexo da mencionada realidade, pois ela a entende como o período compreendido entre a nidação do embrião no útero e o parto. O anterior é relevante... considerando que a prova do aborto supõe a comprovação de uma gestação".

7) Coerentemente, "a doutrina penal mais autorizada, entre a qual se destaca a maioria da doutrina espanhola, sustenta que o bem jurídico protegido pelo delito de aborto só existiria desde a nidação do óvulo fecundado, porque antes não se poderia saber se havia ou não gravidez".

8) Se menciona a existência de "antecedentes científicos que levariam a sustentar que o embrião antes da nidação no endométrio tem uma alta probabilidade de sofrer alterações que podem tornar impossível a expressão de sua individualidade", elemento este que seria essencial para protegê-lo.

9) A "Comissão Interamericana, se referindo ao art. 4.1 do Tratado, em sua Resolução n. 23/81, caso 2141, Estados Unidos da América, de 6 de março de 1981, assinalou que é equivocada uma interpretação da Convenção no sentido de que outorga uma proteção absoluta à vida desde a concepção". 
10) Tão pouco a Convenção sobre os direitos da criança "seria útil para resolver o problema de quando começa a outorgar sua proteção ao direito à vida". Assim, nota, em seu art. $1^{\circ}$ esse tratado internacional 32 , estabelece: "Para os efeitos da presente Convenção, se entende por criança todo ser humano menor de dezoito anos de idade, salvo se, em virtude da lei aplicável tenha alcançado antes a maioridade". Em seu critério, tal Convenção tem por objetivo definir "até quando" e não "desde quando" se reconhecem direitos a indivíduos enquanto crianças.

\section{As razões em que se fundou a maioria para adotar o acordo e ditar a sentença}

Para a maioria, que finalmente decidiu a sentença, prevalecem as razões que levam a considerar inconstitucional o decreto impugnado.

1) Para o Tribunal, a proteção Constitucional do direito à vida alcança o nasciturus que, a seu juízo, é uma pessoa desde a concepção. Insiste em que "o informe apresentado pelo Reitor em Exercício da Universidad Católica de la Santísima Concepción e firmado pelos doutores Juan F. Stecher Miranda e Augusto Rivera Javea, sustenta que 'com a fecundação aparece um indivíduo que contém 46 cromossomas da espécie humana, que se desenvolverá por si mesmo, conta com toda a informação genética necessária para seu desenvolvimento, ele mesmo dirige sua construção e divisão, que vem inscrita em seu ADN, usa o alimento proporcionado por sua mãe, é um ser distinto e distinguível completamente de seu pai e de sua mãe, nenhuma informação adicional Ihe será agregada (...). Este jovem ser humano começa sua viajem a través da trompa de Falópio para chegar ao endométrio, lugar que o albergará durante quase 9 meses. Durante o caminho a este destino, se dividirá inúmeras vezes e mudará de estrutura para poder se implantar no endométrio (...). no momento da implantação ele não sofrerá mudança substancial, não se modificam seus genes nem lhe é agregada outra informação (...) do ponto de vista embriológico, é errôneo o conceito de pré-embrião, porque antes do embrião só existia o espermatozoide e o óvulo.

(Pág. 2). Para aqueles que querem argumentar que o não nascido, particularmente durante o primeiro trimestre de gestação, não é ser humano integralmente porque não possui as características de autoconsciência, intuição, pensamento, memória, imaginação e portanto não merece os direitos e proteções que se dão ao nascido, deve-se dizer que ainda que tais características não estejam desenvolvidas no zigoto, estão presentes os genes para o desenvolvimento do cérebro, onde estas capacidades se encontram. (...) após a fecundação não há experimento científico que possa ser desenvolvido com a intenção de determinar quando o não nascido seria humano; qualquer momento que se usar como linha divisória para marcar o começo 
de uma 'humanidade integral' (...) representa um momento arbitrário sujeito à discussão. (Revista Chilena de Direito. Vol. 28, n. 2, 2001, p. 263-254)';

É assim que para alguns especialistas, a implantação se refere só a uma 'célula' que, surgida como consequência da fecundação e na medida em que se desenvolva pode chegar a constituir um embrião, enquanto que, para outros, o que se implanta é mais que uma célula: é um ser humano plenamente identificável e distinguível de seus pais por sua conformação cromossômica e que surgiu precisamente como consequência da fecundação..."

Para o Tribunal Constitucional, "a singularidade que possui o embrião, desde a concepção, permite observá-lo como um ser único e irrepetivel, credor desde esse momento da proteção do direito e que não poderia simplesmente ser subsumido em outra entidade, nem menos manipulado, sem afetar a dignidade substancial de que goza enquanto pessoa;"

2) Se agrega que "na mesma linha de argumentação se deve recordar que a Convenção Americana de Direitos Humanos - tratado internacional ratificado pelo Chile e vigente - assinala, em seu art. 4.1...: "Toda pessoa tem direito a que se respeite sua vida. Este direito será protegido pela lei e em geral, a partir do momento da concepção. Ninguém pode ser privado da vida arbitrariamente".

3) Os informes científicos disponíveis não são concordantes quanto aos efeitos dos fármacos questionados e deixam aberta a possibilidade de que incidam sobre o óvulo fecundado impedindo sua nidação. Assim o "Informe sobre os Aspectos Científicos e Éticos do Uso do Levonorgestro como Anticonceptivo de Emergência", apresentado "pelo Reitor em Exercício da Universidade Católica do Chile, indica que: o Informe produzido pela Universidade Católica do Chile e trazido pelo Reitor em Exercício dessa Casa de Estudos a esta causa, afirma que 'o termo anticoncepção de emergência é inexato e induz a erro, já que eles podem agir não só como anticonceptivos mas também interferindo na implantação do embrião, quer dizer provocando um aborto precoce" (p. 2 e 3 )"'.

4) Para o Tribunal, ainda que se pudesse sustentar que "as posições dos médicos que inferiram nesta causa, seja a favor ou contra que a 'pílula do dia seguinte', em sua versão de progestina pura de 0,75 mg ou no método combinado uzpe, são equivalentes, uma vez que ambas sustentam, com idêntico vigor e convicção, seu particular ponto de vista"; entretanto, "existe um elemento que, a juízo destes julgadores, neutraliza tal equivalência e que tem a ver com o efeito que se produzirá ao acolher-se uma ou outra posição. Com efeito, se se acolhe a tese dos que sustentam que só existiria um ser humano e por isso uma pessoa desde a implantação do embrião no endométrio, impedindo as pílulas do dia seguinte tal implantação, não haveria atentado contra a vida de uma 'pessoa' nos termos em que a Carta Fundamental entende. 
Ao contrário, se se segue a tese de quem sustenta - como entendeu nosso próprio Constituinte - que a vida começa com a concepção, pela união do óvulo e do espermatozoide, um eventual efeito das pílulas do dia seguinte que impedisse a implantação de um ser vivo — ou de uma pessoa - se transformaria em um aborto, exatamente o contrário da proteção constitucional da vida do que está por nascer imposta pela Constituição ao legislador e que, como todo direito fundamental, impõe a todos os órgãos do Estado a obrigação de respeitar e promover." "Desta forma, a equivalência que poderia existir numa primeira análise entre as posições dos especialistas se rompe, pois uma delas produz um resultado inconstitucional enquanto a outra não.

Portanto, a dúvida - que é razoável - posto que não se possa questionar por este julgador o raciocínio dos peritos na ciência médica - envolve - nem mais nem menos - que uma eventual ofensa à Carta Fundamental".

Em consequência, "para resolver o conflito constitucional proposto e frente à evidência de estarem estes juízes diante de uma dúvida razoável devem-se buscar os critérios hermenêuticos desenvolvidos pela teoria dos direitos fundamentais, por ser essa a matéria do presente requerimento. Nesse sentido, parece necessário ter presente o princípio 'pro homine' ou 'favor libertatis' definido na jurisprudência da Corte Interamericana de Direitos Humanos da seguinte forma: 'Entre as diversas opções deve-se escolher a que restringe em menor escala o direito protegido (...) deve prevalecer a norma mais favorável à pessoa humana' (Opinión Consultiva 5, 1985)".

5) Entende-se decisiva para o juízo de constitucionalidade a consideração da circunstância de que "se os efeitos da anticoncepção podem chegar a afetar ao embrião, isso determinará o que este Tribunal deve realizar".

$\mathrm{E}$, nesse sentido, nota-se que "os especialistas coincidem em que os mecanismos de ação dos aludidos regimes de anticoncepção de emergência dizem respeito a três efeitos: a) Impedir a ovulação; b) Impedir a migração dos espermatozoides para fecundar o óvulo; e c) Impedir a implantação (Horacio Croxatto A. e María Oema Ortiz. "Anticoncepção de emergência com levonorgestro". Em: Sección de temas de Ginecoobstetricia II. Capítulo 27105 (eds.) E. Guzmán, A. B. Lalonde. Editorial Publimpacto, Santiago, 2007, pág. 833, e Informe de la Universidad Católica de Chile, p. 3)."

De todo modo, não deixa de reconhecer, que "existem posições concordes acerca dos efeitos da anticoncepção de emergência quando eles se relacionam com impedir a implantação".

6) A circunstância de que "o direito à vida é, sem dúvida alguma, o direito fundante de todos os demais, pois sem vida, dificilmente tem sentido se referir a outros direitos fundamentais. Como notou o Comitê de Direitos Humanos da Organização das Nações Unidas, em sua Observação 131 Geral sobre o art. 6ำ do Pacto Internacional sobre Direitos Civis e Políticos, o 
direito à vida é 'o direito supremo com relação ao qual não se autoriza suspensão alguma, nem sequer em situações que ponham em perigo a vida da nação'. Tendo agregado que "o direito à vida é o mais essencial desses direitos".

A Comissão Interamericana de Direitos Humanos assinalou, por sua vez, que "o direito à vida é amplamente reconhecido como o direito supremo do ser humano e conditio sine qua non para o gozo de todos os demais direitos".

Ressalta-se também que "A relação entre a vida e a liberdade foi não só objeto das controvérsias relativas ao aborto, mas que sustentaram explicações de alto nível na teoria jurídica, como destaca um dos grandes expoentes contemporâneos em matéria de direitos fundamentais: ' $A$ vida humana tem em abstrato um peso superior à liberdade geral de fazer e de não fazer o que se queira. Assim, a importância que tenha a proteção da vida em uma situação determinada se pode determinar, por sua vez segundo o peso abstrato da vida e segundo seu risco no caso concreto' (Robert Alexy: "Epílogo a la teoría de los derechos fundamentales", em: Revista Española de Direito Constitucional, año 22, n. 66, 2002, p. 38)."

7) Os antecedentes relacionados com o modo pelo qual se informa as usuárias de pílulas anticonceptivas (PAE) dos possíveis efeitos da ingestão de tais fármacos ... Assim, por exemplo, a informação francesa do fármaco NORLEVO, desenvolvido pelo Laboratório HRA-Pharma, comercializado pelos Laboratórios Besins-Iscovesco, na França, e que se distribui em cerca de 50 países do mundo, ... que 'este medicamento é um anticonceptivo de urgência' e que 'a anticoncepção de urgência é um método de reparação que busca evitar a ovulação ou a implantação de um ovo fecundado em caso de relação sexual sem proteção'."

8) O direito à vida é inerente à dignidade humana. Assim o consagrou o mais reputado da doutrina jurídica universal: $O$ conceito de humanidade transcendeu o campo do direito em três pontos da ordem jurídica: 1) No tocante aos Direitos Humanos, como garantia da liberdade exterior indispensável para o cumprimento do dever e, portanto, para a salvaguarda da dignidade humana" (Gustav Radbruch: Introducción a la Filosofía de Derecho, FCE, México, 1978, 3a reimpresión, pág.154).

Trata-se da dignidade humana, que abarca a dignidade da pessoa consagrada no art. $1^{\circ}$ de nossa Constituição, mas que a suplanta seu significado jurídico, tanto positivo como natural. A dignidade, como sustentou Kant 'não tem equivalente' e por isso, é tão complexo defini-la como é simples entendê-la.

A dignidade humana é propriedade da civilização, não de nenhuma convicção religiosa, nem política nem cultural. Trata-se de um traço essencial e indiscutível de um estado de civilização ao qual a humanidade chegou a aspirar. A dimensão jurídica da dignidade se encontra na consagração positiva dos direitos fundamentais e, entre eles, do direito à vida que ocupa esta Magistratura nestes autos. 
Do afirmado se depreende a gravidade que encerra a violação da dignidade humana imersa na vida, especialmente quando ela é acionada pelo Estado. Em várias nações do mundo, hoje é possível encontrar sistemas jurídicos que castigam qualquer forma de aborto; outros que não punem porém nenhuma, por considerar que o direito da mulher decidir sua maternidade é absoluto, e aqueles que desenharam diversas fórmulas para resolver eventuais conflitos de interesse entre os direitos da mulher e os do filho não nascido que leva em seu ventre, fundamentando tais fórmulas em considerações de distinta natureza, como a indicação médica por expor a vida da mãe a perigo ou o estupro, por exemplo.

Pelas mesmas razões ... a anticoncepção de emergência é inconciliável com a Constituição, pois a única justificativa para sua implantação é 'diminuir as gestações não desejadas e suas consequências' (pág. 78); e basta para ter acesso a elas 'não desejar' a gravidez ou, o que é o mesmo 'desejar' utilizá-la."

9) "A tese médico-obstétrica abraçada pelo Poder Executivo, que postula que a vida do que está por nascer adquire relevância jurídica e pode ser vítima de aborto só uma vez que se tenha implantado no útero materno, pode ser muito respeitável e até chegar a se impor no futuro, mas não tem hoje a capacidade de interpretar a Constituição de forma obrigatória nem, menos, de modificá-la".

\section{Os fundamentos dos votos dissidentes}

\section{6.a. Do ministro senhor Juan Colombo Campbol}

1) De acordo com o estudo "MECANISMO DE AÇÃO DO LEVONORGESTRO COMO ANTICONCEPTIVO DE EMERGÊNCIA, publicado na Revista do Centro de Estudos Públicos n. 95, ano 2004, a gestação só estaria assegurada com a implantação do zigoto no endométrio, o que ocorreria por volta de 14 dias seguintes à concepção. Por isso "ao alegar um 'efeito abortivo' os requerentes estão aludindo a um fato que, se efetivo, estaria contemplado como típico no Código Penal, o que torna ainda mais relevante o cumprimento do onus probandi por sua vez, mais ainda quando o aborto na legislação chilena está apenado e estamos em presença de um ato de autoridade, especificamente um decreto firmado pela Presidenta da República e a Ministra da Saúde que, a juízo dos requerentes, promoveria a distribução de medicamentos de efeitos abortivos."

2) O "início exato da vida humana e também, em determinadas condições, o momento da morte, é um tema em que não há consenso, no qual a moral, as ciências e as distintas profissões de fé expõem suas teses, tema 
que não se encontra nem pode ser resolvido completamente pelo direito, ao se colocar assim no plano do exercício da liberdade de consciência, reconhecida pela própria Carta Fundamental, e por outra parte também no plano da pesquisa científica da biologia, a menos que por sentença se negue tal direito fundamental, se imponha com efeito de coisa julgada uma determinada concepção excludente das outras".

O que não seria adequado ao ordenamento porque "a jurisdição deve apenas resolver conflitos de direito, definidos como aqueles nos quais o parâmetro de julgamento seja constituído por normas jurídicas, neste caso de grau constitucional. No caso sub lite, os requerentes sustentam ademais sua pretensão em normas de ordem moral e em algumas das correntes da ciência médica, muito além das normas constitucionais invocadas". Por isso, "o conflito submetido à resolução desta Magistratura não se encontra regulado pelo sistema jurídico, sendo um tema que se desenvolve no marco da liberdade de consciência e de crenças, não existindo, como já se disse, consenso científico a respeito dos fatos a ele relativos" e por esta razão não estaríamos "em presença de um conflito de interesse de relevância jurídica constitucional daqueles que devam dar origem ao exercício da função jurisdicional, e a consequente prolação de uma sentença que o resolva, por parte deste Tribunal".

\section{6.b. Voto dissidente do ministro senhor Hernán Vodanovic Schnake}

1) Nota que o que se discute são "dois assuntos de capital importância: 1) A existência, grau e entidade dos direitos do embrião pré-implantacional, e 2) $O$ eventual conflito entre um interesse constitucionalmente protegido $e$ outros direitos fundamentais, como os de ordem reprodutiva e sexual".

E chega à conclusão de que "o nasciturus não é titular dos direitos fundamentais reconhecidos pela Constituição, que a Carta Fundamental não proíbe o aborto, que os mencionados direitos reprodutivos têm reconhecimento constitucional e, por último, que o interesse preponderante - se existir um conflito de valores de relevância constitucional - recai nos direitos fundamentais da mulher".

2) Parte da ideia de "que os direitos fundamentais podem ser conceituados de forma ampla, como faz Luigi Ferrajoli", assinalando que são "aqueles direitos subjetivos que pertencem universalmente a todos os seres humanos dotados de status de pessoas. Dessa perspectiva, a titularidade dos denominados direitos fundamentais reside na pessoa ou em grupos determináveis de pessoas".

3) Nota ademais que os "direitos, enquanto valores substantivos e autônomos, emanados da dignidade do ser humano, devem ser diferenciados 
claramente das denominadas garantias, que enquanto instituições jurídicas de caráter adjetivo, técnicas ou ferramentas, buscam assegurar os direitos".

4) Para ele se podem distinguir "dois valores: a vida humana consolidada e plena, amparada pelo direito à vida, por ser pessoa e sujeito de direito seu titular e, por outra parte, a denominada 'vida por nascer', que não é reconhecida como pessoa, e que pode vir a ter um certo estatuto jurídico de proteção e de titularidade de direitos eventuais condicionados ao nascimento.

Nesse sentido, se o direito à vida aparece como um direito fundamental e, portanto, de caráter subjetivo e de titularidade da pessoa, a proteção da vida por nascer não parece ser uma garantia do direito à vida, pois opera num espaço temporal no qual não existe o direito que seria objeto de tal garantia.

Do mesmo modo, o direito à vida de que gozam as pessoas se entende universalmente como o direito a não ser privado dela arbitrariamente, norma reconhecida, por exemplo, no Pacto de San José de Costa Rica. Ele se traduz na existência de causas de justificação, como o estado de necessidade a legítima defesa.

Pode-se afirmar então que não existe fundamento para sustentar, como o fazem os requerentes, que o aborto goza de uma proscrição constitucional, mais ainda se da própria Carta Fundamental não se depreende nenhuma norma, o que é especialmente relevante tendo em conta o princípio de autonomia do legislador, a reserva legal em matéria penal e a tipificação do aborto no Código Penal, corpo de grau legislativo".

5) Reforça também o alcance do "Pacto de San José da Costa Rica, que protege o direito à vida 'em geral, a partir do momento da concepção'”.

$O$ alcance de tal frase se encontra nos trabalhos preparatórios desse tratado, de cujas atas consta que na segunda sessão plenária da Conferência de San José, as delegações de Estados Unidos e Brasil consignaram a seguinte declaração: 'Estados Unidos e Brasil interpretam o texto do parágrafo 1 do art. 4 no sentido de que deixa à discrição dos Estados-Parte o conteúdo da legislação à luz de seu próprio desenvolvimento social, experiência e fatores similares' (Conferência Especializada Americana sobre Direitos Humanos, Ata da segunda sessão plenária, OEA/Ser.K/XVI/1.2, p. ó). Do mesmo modo, nas sessões de preparação do texto em San José se reconheceu que a frase 'em geral, a partir do momento da concepção' deixava aberta a possibilidade de que os Estados-Parte numa futura Convenção incluiriam em sua legislação nacional 'os casos mais diversos de aborto'. (Conferência Especializada Interamericana sobre Direitos Humanos, OEA/ Ser.K/XVI/1.2, p. 159)".

6) $O$ exposto foi reafirmado pela Comissão Interamericana no caso conhecido como "Baby-boy vs. Estados Unidos", mediante a resolução 23/ 81 , de 6 de março de 1981. 
7) Incidiria na solução do problema, um conjunto de direitos que compreende "a integridade física e psíquica, a liberdade pessoal, a liberdade de crenças e o direito à vida privada, conjunto de direitos que atribuem à mulher liberdade para decidir quando deseja viver ou não a maternidade, de forma livre e consciente."

Neste sentido, o uso de anticonceptivos e o direito a dispor da maternidade por parte da mulher é um tema antigo e já resolvido no direito constitucional comparado no terceiro terço do século $X X$.

Os direitos fundamentais no constitucionalismo contemporâneo cumprem a função de ser o limite do poder do Estado e de constituir, ademais, sua justificação, gozando, em razão de sua função, das máximas hierarquia e força normativa dentro do sistema constitucional.

Isso implica que os direitos delimitam a órbita de ação do Estado e aquela esfera de exercício de liberdade que não pode sofrer interferência dele, de modo que apenas num âmbito alheio ao exercício do que se denomina o núcleo essencial de tais direitos poderá o Estado intervir."

8) "O anterior resulta fundamental para fins de discernir qual é a fronteira do mandato do legislador para proteger a vida do que está por nascer, pois se tal limite é dado pelos direitos fundamentais, o Estado não pode ultrapassá-lo, nem sequer com o pretexto de proteger um interesse constitucionalmente relevante, pois se tal ato implica a negação ou ofensa de um direito fundamental, o meio utilizado é ilícito, ademais de negar e ofender a hierarquia."

9) Entende também que "prescindindo do arrazoado precedente, procede concluir que no exercício desse mandato de ação legislativa, e realizando uma ponderação dos bens protegidos, deve-se ter presente como premissa básica que o Estado não pode invadir o espaço da vida privada e da liberdade de consciência, e sobretudo, a esfera do livre desenvolvimento da pessoalidade, concretizada específica e detalhadamente nos direitos reprodutivos e sexuais da mulher, direitos fundamentais que limitam o poder do Estado e que gozam de preponderância e maior força normativa frente ao resto dos interesses constitucionais, pelo que qualquer meio utilizado neste contexto resulta contrário à Constituição."

10) "No mesmo marco de ponderação, cabe notar que se o direito à vida admite situações de inexigibilidade, tais como a legítima defesa ou o estado de necessidade, nas quais a privação da vida é amparada pelo direito, com maior razão é dado concluir que a vida por nascer, protegida com menor intensidade e ponderada frente a direitos fundamentais da mulher, admite situações em que seus pressupostos de proteção decaem, entre as quais se encontra, desde já, o exercício legítimo de direitos fundamentais de natureza reprodutiva, sem prejuízo de outras de fonte claramente penal, como a lex artis médica no exercício legítimo da medicina e a carência do 
elemento malícia exigido pelo tipo de aborto." E se deveria também ter em conta que "o primeiro efeito do suposto direito é a obrigação da mulher de suportar o estado de gestação, hipótese que tampouco é absoluta, pois ao colidir com direitos fundamentais, deve-se ponderar a finalidade, meios utilizados e idoneidade da proteção da vida por nascer; isto é, os meios empregados devem ser proporcionais ao resto do ordenamento constitucional, aptos e proporcionados à entidade e relevância da vida por nascer e ao exercício dos direitos da mulher grávida. Resulta obvio que em gestações inviáveis, em situações de risco de vida e integridade da mulher e, em geral, frente à afetação de outros direitos fundamentais relevantes, a proteção absoluta da vida por nascer neste contexto é desproporcional e inclusive pode chegar a ser ineficaz.

A exigibilidade dos direitos fundamentais da mulher e a eventual exigibilidade dos direitos supostos de um indeterminado titular denominado 'vida por nascer', aparecem evidente e claramente diferenciados. Fica manifesto que a exigibilidade dos direitos da mulher é imediata, concreta e definida, não ocorrendo o mesmo no caso do nasciturus, pela indeterminação de seu estatuto, por não ser reconhecido nem reconhecível como pessoa e, por isso não ser identificável pessoa alguma como titular de tal proteção, em termos de gozo de legitimidade ativa para reclamá-la."

11) Diz, ademais, que "não cairá na tentação de pretender resolver pelo caminho da jurisdição ou debate ético científico acerca do início da vida, questão que deveria estar claro que não compete ao direito dirimir, apesar da pretensão dos requerentes.

Indica em tal sentido que "a Corte Suprema Federal, em relação à possibilidade de estabelecer em sede jurisdicional o momento do inicio da vida, notou que 'se os médicos, os teólogos ou os filósofos são incapazes de se por de acordo a respeito, os tribunais não estão em condições de especular com a resposta' ("LAS SENTENCIAS BÁSICAS DEL TRIBUNAL SUPREMO DE LOS ÉTADOS UNIDOS", BOTRAN DE FOIPE, MIGUO, BOE, MADRID, AÑO 2006, PAG. 419")."

Por isso, "resolver sobre as diferentes concepções acerca do início da vida, não é uma matéria própria desta sentença" especialmente tendo em conta que "nosso regime constitucional proclama a liberdade de consciência e de crenças". O contrário, "implicaria abdicar da laicidade e neutralidade dos órgãos e espaços públicos, que se devem abster de invadir esse campo, mais ainda em um regime republicano como o que proclama o art. $4^{\circ} \mathrm{da}$ Constituição."

Agrega que o "efeito real da declaração de inconstitucionalidade impetrada é lesivo à essencial função de administrar o Estado, que incumbe ao Executivo, perturbando gravemente a formulação e execução de políticas públicas de saúde." E que representa "também, uma incoerência atribuir 
riscos abortivos a medidas de anticoncepção reconhecidas universalmente, cujo emprego - em um tempo muito próximo ao da relação sexual - tem por uma de suas finalidades essenciais precaver a ocorrência efetiva de abortos numa etapa avançada da gestação."

\section{6.c. Voto dissidente dos ministros senhores Jorge Correa Sutil e Francisco Fernández Fredé}

1) Para estes ministros, "os métodos de anticoncepção hormonal de emergência que estão contidos na sessão 3.3 do Decreto aludido, não atentam contra a vida do que está por nascer nem contra a dignidade humana".

2) Resulta decisiva a circunstância de que "a evidência invocada pelos requerentes e a acumulada ou mencionada neste processo não permitem sustentar sequer uma dúvida razoável acerca dos métodos de anticoncepção hormonal de emergência contidos na sessão 3.3 do Decreto Supremo impugnado sejam capazes de impedir o desenvolvimento de um embrião humano. Não negamos que os cientistas mantêm uma polêmica a respeito dos efeitos do sistema anticonceptivo hormonal de emergência; mas a existência de tal polêmica não é suficiente para sustentar que exista uma dúvida razoável acerca dos efeitos antinidatorios ou impeditivos do desenvolvimento do embrião humano. Tampouco o são as legendas ou rotulações dos respectivos produtos."

4) Assinalam que "O debate entre as partes e a informação disponível no processo permitem ter por estabelecidos alguns fatos não discutidos, quais sejam:

a) que tanto a pílula do dia seguinte como o uzpe são anticonceptivos eficazes. Com efeito, e segundo se justificará mais adiante, não existe debate entre as partes nem entre os peritos que expuseram no Tribunal, no sentido de que estes fármacos têm capacidade anticonceptiva, enquanto dificultam a ovulação.

b) que estes fármacos não afetam a vida do embrião uma vez implantado ou, ao menos, que não existe evidência alguma disso.

O que as partes contestam é o efeito que a pílula e o uzpe produzem ou podem produzir sobre o embrião na etapa prévia a sua nidação. Os requerentes e vários peritos sustentam que estes medicamentos, ademais de efeitos anticonceptivos, têm a capacidade de matar o embrião antes de sua implantação ou de evitar sua nidação ou aderência ao corpo da mulher, o que impede seu desenvolvimento e produz sua morte ou, que, ao menos, existe uma dúvida razoável acerca desse efeito. O governo e outros peritos sustentam que não existe antecedente algum que permita sustentar que a pílula, ademais do efeito anticonceptivo, tenha capacidade de afetar o embrião entre o seu surgimento, com a fecundação, e o momento da nidação. 
"Os requerentes argumentam que, nesse caso, basta que a prova seja capaz de colocar uma dúvida. Notam que, em se tratando de direitos fundamentais, e particularmente do direito à vida, deve-se sempre interpretar a dúvida em prol do valor da vida. Agregam que em se tratando de fato que deve ser provado, a prova completa do caráter abortivo exigiria experimentar com embriões para ver se os matam, o que é ética e legalmente proibido. Nesse sentido, deve-se dar razão, particularmente porque se trata da imputação de que um fármaco pode produzir a morte, os efeitos do fato são de todo irreversíveis. Em consequência, a juízo destes dissidentes, bastaria que a prova produzisse uma dúvida razoável de que o fármaco autorizado possa produzir a morte de um titular do direito à vida (o que também é debatido nos autos no sentido de que o zigoto o seja). Em consequência, enquanto o adequado funcionamento do sistema democrático exige que a afirmação de nocividade do fármaco já autorizado seja provada, o valor da vida e o caráter irreversível da morte fazem com que seja suficiente uma dúvida razoavelmente motivada e crível.

A análise da evidência científica disponível. "é indicativa de que a pílula do dia seguinte não tem efeito algum sobre a produção da ovulação e, por isso, carece de aptidão para afetar o desenvolvimento do ovo fecundado. Ainda que se tenha discutido, com razões não depreciáveis, que essa evidência não é concludente no sentido indicado, o importante, para os efeitos de resolver a questão que nos ocupa, é que a prova não estabelece a dúvida razoável dos efeitos mortíferos da pílula sobre o embrião, como pretendem os requerentes." ... pois ... "indica que os fármacos implicados na anticoncepção de emergência a que alude o Decreto Supremo não produzem efeitos sobre o endométrio que diminuam sua capacidade de nidar o embrião.

O que é decisivo para a presente causa ... (é que) a evidência científica apresentada não permite dar sustento à dúvida contrária, isto é, a que efetivamente o levonorgestro tenha capacidade de impedir a nidação do embrião. Não existe evidência alguma invocada ante o Tribunal que assim o sustente para o levonorgestro puro (pílula do dia seguinte) e a única que lhe dá sustento no caso da combinação de levonorgestro com etinil estradiol, é com dose muito superior àquela que o Decreto impugnado ordena aconselhar.

A evidência científica analisada acredita que os métodos de anticoncepção hormonal de emergência são eficazes para prevenir gestação. Também acreditam que isto se deve, em tudo ou em parte, segundo se discute, a sua capacidade de impedir a ovulação na mulher. Também existe evidência indiciária de que dificultam a viagem dos espermas ao óvulo, ainda que isso se discuta e não esteja plenamente provado. Nenhum dos efeitos antes mencionados se poderia considerar contrário à Constituição, pois não é prevenir a fecundação. Discute-se se os fármacos poderiam interferir com o embrião e é difícil uma prova certa e definitiva pelos problemas de se experimentar com embriões. A experiência com animais conduzem a concluir que 
não há tais efeitos contrários ao desenvolvimento do embrião, mas se discute se tais conclusões podem ser extrapoladas a humanos. A evidência que mediu o efeito do levonorgestro em outras condições do aparato reprodutor feminino é indicativa de que não tem capacidade de alterar seu desenvolvimento ou nidação. O mesmo se pode dizer do uzpe, salvo quando se empregue com dose de levonorgestro muito superior àquela que recomendam as normas impugnadas.

Em consequência, nesta causa não se provou a existência de uma dúvida razoável de que um ou outro dos métodos que a norma questionada ordena aconselhar, nem a pílula de levonorgestro puro que ordena distribuir, são capazes de impedir a nidação de um embrião humano, de impedir seu desenvolvimento ou de provocar sua morte por qualquer outra via.

Por sua vez, a rotulação voluntária ou obrigada do produto, ainda que conste que tenha sustentado ou sugerido que possa ter efeito sobre o embrião, não afirma que ele seja um fato certo ou uma dúvida razoável. Informar que se sustenta um fato não constitui evidência alguma acerca da probabilidade de sua certeza e, a nosso juízo, não pode fundar sua proibição por um tribunal, máxime em uma matéria dessa transcendência."

4) Nota-se também que "ao se concluir assim, se coincide com o resolvido pela Corte Suprema de Justiça que, em julgado de 28 de novembro de 2005, rejeitou uma ação de nulidade de direito público contra o registro da mesma pílula que o Decreto agora impugnado ordena aconselhar e distribuir.

Havendo-se chegado à conclusão de que a prova apresentada nesta causa não permite afirmar que a pilula do dia seguinte tenha efeitos mortais sobre o embrião, nem que sobre ele exista uma dúvida suficientemente razoável, não é necessário continuar com a análise para recusar o requerimento.

Redigiram a sentença os Ministros senhores José Luis Cea Egaña, Raúl Bertosem Repetto, Mario Fernández Baeza, Marcoo Vemegas Palacios e señora Marisol Peña Torré. A prevenção, os votos concorrentes e as dissidências foram redigidas por seus autores. A que subscrevem conjuntamente os Ministros senhores Correa Sutil e Fernández Fredé, o primeiro deles.

\section{ANÁLISE DAS POSIÇÕES EM CONFRONTO NA PERSPECTIVA DO DIREITO URUGUAIO}

\section{A colocação do problema}

O exame da sentença e dos argumentos a favor e contra, com relação à questão da constitucionalidade de uma norma que admite e permite a 
comercialização de fármacos e procedimentos que podem ter por efeito impedir a nidação de um óvulo fecundado (que por comodidade de hipótese, vamos supor de base ou fundamento legal, a fim de que as conclusões admitam um maior grau de generalização e sejam extrapoláveis a outros ordenamentos jurídicos), gira substancialmente em torno de três eixos:

a) o alcance da proteção constitucional do direito à vida;

b) quando se adquire a qualidade de pessoa;

c) o efeito dos fármacos e procedimentos questionados sobre o ser que tem tal qualidade.

Ainda que os assinalados sejam os elementos medulares, não há dúvidas de que outros tenham também papel importante e até decisivos para resolver o espinhoso problema que se estuda.

O primeiro é o relativo ao grau de certeza que se possa constatar acerca dos efeitos antinidatorios dos referidos fármacos e procedimentos. Não são por certo iguais as situações se existe certeza ou quase certeza de que tal efeito se verifica ou se, ao contrário - nos extremos - se chega à convicção de que ele não se produz. Entre os dois extremos luminosos de certeza pode haver uma zona cinzenta de incerteza (e de fato parece ser 0 caso da espécie analisada) que pode variar desde uma simples dúvida a uma dúvida razoável.

O segundo é o relativo ao onus probandi, ponto de especial relevância na hipótese da zona cinzenta.

O terceiro é o referente ao conflito entre o direito à vida e outros direitos, como o relativo à livre determinação da mulher e, em particular, o referido a seus direitos sexuais e reprodutivos. Nesse caso, a colocação e a solução podem ser diferentes segundo exista ou não certeza a respeito dos efeitos dos fármacos e procedimentos citados.

O quarto diz respeito à interferência da questão que se analisa com os fins e políticas de saúde pública.

O quinto se vincula, como em princípio se notou, com o método de interpretação que se considere adequado e à concepção do ordenamento jurídico.

Quero notar também que a análise das referidas questões será feita da perspectiva do direito uruguaio, ainda que, dadas as razões que estão em jogo, as conclusões a que se chegue poderão ser, em geral, aplicáveis a outros ordenamentos que tenham Constituições que consagram uma carta de direitos e ordenamentos jurídicos similares à nossa (que, quanto ao direito à vida são praticamente todas). E, além disso, dado que boa parte dos argumentos e das razões referentes à constitucionalidade ou inconstitucio- 
nalidade de uma normativa que admita a utilização de fármacos como o lemovorgestro tenha sido exposta na sentença comentada, sem prejuízo de fazer-Ihes referência, não se voltará a realizar uma exposição e análise detalhada deles ${ }^{(10)}$.

\section{Alcance da proteção constitucional do direito à vida}

\section{2.a. Os arts. $7^{\circ}$ e 72 da Constituição}

Os arts. $7^{\text {(111) }}$ e 72 da Constituição uruguaia(12) são as duas normas medulares para colocar e resolver a questão. A primeira estabelece a) o direito ao gozo da vida e dos outros direitos que menciona; e b) que ninguém pode ser privado desses direitos, a não ser por uma lei fundada em razões de interesse geral.

O texto constitucional suscita dois problemas: a) o de que se contempla ou não o direito à vida; e b) em caso afirmativo, quem seria seu titular.

Ainda que para alguns o significado que se deva dar à disposição é o de que é uma norma que regula estritamente (e conforme à literalidade do texto) o direito ao gozo da vida, ele não tem, entretanto, uma importância decisiva, pois, mesmo aqueles que têm esta postura consideram que o direito à vida está implicitamente previsto por tal norma, já que necessariamente o direito ao gozo da vida se pressupõe ou se infere do art. $72^{(13)}$.

Este, como ressalta nossa melhor doutrina(14), vem a positivar o chamado jusnaturalismo clássico e consagraria (para alguns seria mais preciso dizer, declararia), inequivocamente, porque inerente à pessoalidade, o direito à vida (que preexistiria ao texto constitucional, que se limitaria a reconhecê-lo).

(10) Basta, com efeito, examinar alguns dos estudos sobre o tema para constatá-lo. Nesse sentido, veja-se o citado opus de LANZIANO, Wáshington, p. 13 y ss. e o estudo multidisciplinar ABORTO en debate. Dilemas y desafíos del Uruguay democrático. Disponible en: <www.leyaborto.org/esp/publicaciones/libros.php>.

(11) Art. $7^{\circ}$ "Os habitantes da República têm direto a ser protegidos no gozo de sua vida, honra, liberdade, segurança, trabalho e propriedade. Ninguém pode ser privado desses direitos senão conforme às leis estabelecidas por razões de interesse geral."

(12) Art. 72. "A enumeração de direitos, deveres e garantias feita pela Constituição, não exclui os outros que são inerentes à personalidade humana ou derivados da forma republicana de governo." (13) Assim MANZONI RUBIO, Luis B. Constitución y aborto. Revista de Derecho Público, año 13, n. 26 , p. 85,2004 , nota que, dada a clara inerência à personalidade humana do direto à vida, ele "sempre foi considerado implícito ao art. 72, e assim deve ser desde que a ninguém ocorreria o contrário".

(14) Ver por todos, RAMÓN REAL, Alberto. Los principios generales de derecho en la Constitución Uruguaya: vigencia de la estimativa iusnaturalista. Montevideo: Ed. Librería Juan A. Peri, 1958. 


\section{2.b. $O$ direito à vida se encontra reconhecido na Constituição. Limitabilidade por leis ditadas por razões de interesse geral}

Para uma tese, o direito à vida não é susceptível de limitação por lei. Os argumentos centrais desta posição consistem em considerar que o direito à vida não somente tem reconhecimento constitucional, sendo que o único susceptível de limitação, de acordo com o art. $7^{\circ}$, é o direito a seu gozo. Portanto, toda lei que admitisse a possibilidade de se limitar ou privar do direito à vida seu titular seria inconstitucional.

Nessa linha de pensamento, Risso Ferrand ${ }^{(15)}$ sustenta que a vida é um direito que 0 art. $7^{\circ}$ da Constituição reconhece como preexistente, sendo um bem jurídico que não pode ser objeto de nenhuma limitação ou privação. Só o direito a ser protegido em seu gozo pode ser objeto de modificação pelo legislador. Para exemplificar seu pensamento, menciona o caso de uma norma legal que obrigasse os cidadãos de um Estado a defendê-lo em caso de conflito bélico, o que implicaria uma clara restrição ao direito ao gozo da vida.

\section{Argumentos contrários à tese da ilimitabilidade}

O ponto não deixa de ser discutível, pois o fato de que o constituinte não tenha previsto em forma expressa a possibilidade de sua limitação, não implica necessariamente que o direito à vida não seja limitável, pois se assim o fora, nenhum dos direitos inerentes à pessoalidade que não fossem previstos expressamente (mas que tivessem fundamento no art. 72) seriam susceptíveis de limitação, o que parece difícil de admitir.

Por outra parte, a admissibilidade de tal premissa poderia levar a conclusões inaceitáveis, como, por exemplo, a inviabilidade de regular a legítima defesa e o estado de necessidade como causas de justificação que excluem a antijuricidade do homicídio. E não explicaria coerentemente porque o constituinte sentiu a necessidade de ditar uma norma que proíbe a pena de morte (art. 26) ${ }^{(16)}$.

Risso não se pronuncia claramente sobre a constitucionalidade de uma lei que legalize o aborto, mas parece inclinar-se pela negativa, fazendo

(15) RISSO FERRAND, Martín. Síntesis de la regulación constitucional de los derechos fundamentales en el Uruguay. Revista de Derecho Constitucional y Político, t. 12, n. 67/71, p. 652-653, jun. 1995, mar. 1996.

(16) Esta regra como nota Risso (ob. cit. p. 652), não admite exceções. Ademais, deve-se ter em conta que o Uruguai, pela Lei n. 16.461, de 31 de dezembro de 1993, aprovou o Protocolo da Convenção Americana de Direitos Humanos, relativa à abolição da pena de morte. Ver em sentido similar, GOROSITO ZULUAGA, Ricardo. El derecho a la vida, su protección constitucional. Revista Uruguaya de Derecho Constitucional y Político, t. 11, n. 62, p. 157-159, ago./set. 1994. 
referência a que 0 art. $7^{\circ}$ da Constituição deve ser interpretado harmonicamente com o art. 42 que protege a maternidade e tendo presente o Pacto de San José de Costa Rica (ratificado como se disse pelo Uruguai), que reconhece o direito ao respeito à vida desde a concepção. Na solução do problema incidirão em alto grau, como se notou nas precisões iniciais, as concepções que se aceitem quanto à natureza e o alcance da interpretação. Assim, tendo-se determinado que no marco de referência da norma ou conjunto de normas a serem interpretadas (no caso, fundamentalmente, os arts. $7^{\circ}$ e 72 da Constituição) se podem individualizar vários significados possíveis, será o legislador (ou o Juiz) quem livremente, por razões de política legislativa, ética ou moral (que para Kelsen são metajurídicas) vai decidir por qual optar. Distinta será a postura de quem não aceite este enfoque ou o admita com variantes que incidam na solução do problema, por exemplo, esgotando as possibilidades de eleição em função dos valores que formam parte do sistema.

\section{2.c. A titularidade do direito à vida}

Há três pontos sobre os quais é fácil se pôr de acordo e que evidentemente (ao menos na atualidade) não requerem que se abunde em sua demonstração:

a) o titular do direito à vida é a pessoa, à qual é inerente;

b) todo ser humano é pessoa(17); e

c) se tem a qualidade de ser humano e de pessoa desde o nascimento(18).

O que está em tela de juízo é se a dupla qualidade de ser humano e de pessoa existe antes do nascimento e em todo caso, desde qual momento.

\section{3. $O$ embrião(19) e o direito à vida}

A questão do embrião ter direito à vida tem sido objeto de uma multiplicidade de teorias (o que é particularmente evidente se examinada em sua pers-

(17) Há mais de meio século, Quintín Alfonsín sustentava que "atualmente vige uma norma material de direito privado internacional, segundo a qual todo ser humano é pessoa", com a conseguinte ilegitimidade de situações admitidas no passado, como a escravidão e a morte civil (QUINTíN, Alfonsín. Sobre la existencia de las personas en derecho privado internacional. In: Estudios Jurídicos en memoria de Juan José de Amézaga. Montevideo: Facultad de Derecho y Ciencias Sociales, Montevideo, 1958. p. 13). Assim, se hoje o princípio de que todo homem é pessoa é um dado da realidade a que ninguém ocorreria questionar, no passado nem sempre foi assim, bastando recordar para exemplificá-lo que era juridicamente admissível a escravidão (e a conseguinte coisificação do homem).

(18) Em alguns casos, a legislação exige requisitos complementares, como, por exemplo, os arts. 216 e 835 de nosso CC, cujo alcance pode ser visto nos estudos mencionados na nota número 20. (19) Em sentido amplo, abarcando suas diversas manifestações a partir do zigoto. 
pectiva histórica). A maioria delas, envolvendo a da identidade genética, a da autoconsciência, a da atividade cerebral etc. não será examinada neste estudo.

Só se verá a tese negativa, examinada desde a ótica da falta de independência do feto, a teoria da concepção (em suas grandes linhas, pois apresenta múltiplas variantes) e a da nidação, que são as que têm mais incidência no caso que se comenta.

\section{A tese negativa. A colocação desde a perspectiva da independência do ser}

Um dos lados da questão, a meu juízo desacertado, se constrói sobre o eixo da dependência ou independência do ser humano que se considere. Assim, tomando-se em conta como um dos traços identificadores da pessoalidade a característica mencionada em segundo lugar, o feto não deixaria de ser dependente até o momento do nascimento e então seria pessoa (mesmo quando se entenda que sua situação até a mudança de status deva ser contemplada mediante normas protetivas, como quase sempre se fez ao longo da história nos distintos ordenamentos jurídicos)(20).

Um enfoque desse tipo foi realizado entre nós por Abadie Santos, para quem o:

feto não tem personalidade. Qualificamos de sofísticos os argumentos de índole jurídica organizados para parear o homicídio e a supressão do gérmen humano ... Antes que um ser distinto apareça livre do álveo materno, pode-se falar de um direito distinto do direito do ser ao qual está subordinado? Ontologicamente pode-se sustentar a proposição, desde logo, frente a terceiros não autorizados; mas discutível no caso em que a vida do embrião se perfile em relação de fatal incompatibilidade com a sobrevivência da mãe(21)

Em sentido similar se sustentou que "o gozo dos bens humanos fundamentais pressupõe, ao menos, a independência biológica que o embrião não tem, sem a qual não é concebível aquele gozo"(22).

(20) Esta tese prevaleceu até a ratificação do Pacto de San José de Costa Rica (Ver GAMARRA, Jorge; BLENGIO Juan E. Tratado de derecho civil Uruguayo. Montevideo: FCU, 2000, t. 10, p. 4748). Ela se fundamenta basicamente nos arts. 21, 216, 3o, do Código Civil e entendendo que ainda que certas normas como os arts. 1617, 216 inc. 3‥ e 835 do mesmo Código contemplem os direitos do concebido, fazem-no com a previsão de seu nascimento. Assim DEL CAMPO, Francisco. Personas. Montevideo: Medina, 1962. p. 14 y ss., aunque para autores como CESTAU, Saúl. D. civil: primer curso. Apuntes de clase, 1966. p. 93 e GATTI, Hugo E. Personas. Montevideo: Acali, 1977. t. 1 , p. 36 y ss. se requeriria, ademais, a viabilidade e viver 24 horas naturais.

(21) ABADIE SANTOS, Horacio. La impunidad del aborto consensual. Montevideo: Ed. Larre \& Cía., 1935. p. 53.

(22) MANZONI RUBIO, Luis B. op. cit., p. 84. Ver também CASSINELLI MUÑOZ, H. Protección en el goce de bienes fundamentales y acción de amparo. Revista Colegio de Abogados del Uruguay, t. 36, nov. 1993. 
Foi dito também que o art. 7ํ, ao referir à titularidade do direito ao gozo da vida aos habitantes, excluiria de seu âmbito o feto "por clara inadequação de sua situação intrauterina com a de habitante, que é geográfico-jurídica ${ }^{(23)}$. Em um sentido similar, Lanziano (que por outras considerações sustenta a posição de que o concebido é titular do direito à vida) afirma que: "os seres humanos antes de nascer não são habitantes - nem são considerados nos censos populacionais"(24)

Ademais, certas normas, especificamente preordenadas à tutela do direito à vida, como o art. 26 da Constituição, que dispõe que "a ninguém se aplicará a pena de morte", são "claramente inadequadas para a proteção da vida humana embrionária”(25).

Manzoni considera que com base nesse argumento se poderia chegar à conclusão de que não existe, em nossa Constituição, qualquer norma que de maneira explícita "proteja a vida do feto"(26). Assim, se a solução da questão dependesse desse tipo de previsão, se deveria concluir que o legislador teria liberdade para estabelecer a solução que quisesse quanto ao aborto(27). Sustenta também que é necessário separar o direito à vida "de um possível e mais concreto direito de proteção da vida do feto", e que "além da diferente configuração ontológica de cada um, não parece possível estender a titularidade do primeiro mais além das pessoas físicas nascidas"(28). Entretanto, com base em uma interpretação segundo a qual o art. 72 responde, mais que a uma concepção aparentada com o jusnaturalismo, à outra de tipo sociológico, conclui que "a limitabilidade ou não legislativa do direito recepcionado pelo 72 , seria definida também pela convicção coletiva de sua validade e limitabilidade ou ilimitabilidade"(29). Entende, assim, que se houver "uma convicção normativa ou pré-normativa sobre o aborto, o direito que disporia da ilicitude do aborto, ainda que não necessariamente sua penalização, seria um direito subjetivo de todos os habitantes, sem prejuízo do reconhecimento de titularidade especial, a que não se extinga voluntariamente a vida do feto, salvo para salvaguardar a da gestante"(30). Naturalmente, é bom notar de modo especial, a conclusão, ainda no marco desta posição doutrinária, poderia ser muito diversa, em caso de se demonstrar que a convicção coletiva fosse outra.

A meu juízo, enfocar a questão do nascimento da pessoalidade desde a perspectiva acima, e em particular centrando-a na independência do ser(31)

(23) MANZONI RUBIO, Luis B. op. cit., p. 84.

(24) LANZIANO, Wáshington. op. cit., p. 129.

(25) MANZONI RUBIO, Luis B. op. cit., p. 84.

(26) Id., loc. cit.

(27) Id., loc. cit.

(28) Id. Ibid., p. 85.

(29) Id. Ibid., p. 92.

(30) Id. Ibid., p. 96.

(31) Ver sobre esse ponto, LANZIANO, Wáshington. op. cit., p. 111. 
a quem se reconhece a titularidade do direito à vida, não me parece compartilhável, pois deixa na obscuridade o elemento central da figura: sua individualidade. $\mathrm{O}$ que realmente importa é determinar quando se está em presença de um ser dotado de individualidade, de traços identificadores que o fazem alguém único, um ser distinto da mãe em cujo ventre se gesta(32). Por outra parte, insistir em uma espécie de sociologismo para de algum modo substituir um fundamento jusnaturalista (especialmente com relação ao art. 72) é pelo menos questionável, mas, a análise do ponto excede notoriamente ao objeto deste estudo.

\section{A personalidade antes do nascimento. $O$ momento em que surge a individualidade genética como ponto de começo da personalidade $A$ tese da concepção}

O enfoque da questão da perspectiva indicada no título tem como elemento central a constatação de que com a concepção surge um novo ser dotado de uma individualidade específica, que o faz único, distinto de sua mãe e de seu pai e de todos os demais seres, como demonstraram os estudos sobre o genoma humano(33).

Este enfoque foi precisamente o da Presidência da República ao vetar a lei que despenalizava o aborto:

A legislação não pode desconhecer a realidade da existência de vida humana na etapa de gestação, tal como de modo evidente revela a ciência. A biologia evoluiu muito. Descobrimentos revolucionários, como a fecundação in vitro, e o ADN com a sequenciação do genoma humano, evidenciam que desde o momento da concepção existe ali uma vida humana nova, um novo ser. Tanto é assim que nos modernos sistemas jurídicos - incluído o nosso — o ADN se transformou na "rainha das

(32) Ver em igual sentido, DELPIAZZO, Carlos E. Dignidad humana y derecho. Montevideo: Universidad de Montevideo, 2001. p. 28. Não me parece entretanto compartilhável a posição de FERRAJOLI, Luigi. La questione del embrione tra diritto e morale. Politeia, n. 65, p. 20, 2002, que entende que a tese de que o embrião é uma pessoa não é empírica, mas moral, que, como tal, não é nem verdadeira nem falsa, o que ainda que possa ser compartilhado por muitos não o será certamente por todos. Por isso, sustenta, impô-la juridicamente àqueles que não a compartilham estaria em desacordo com o liberalismo e a laicidade do direito. Não posso por certo me deter na consideração da tese do grande autor italiano, me limitarei a notar que existe um fundamento científico, sobretudo a partir dos estudos sobre o ADN e o genoma humano, para individualizar plenamente a existência de ser único, de um indivíduo distinto de todos, que manterá sua identidade ao longo de toda sua existência. Assim, se o ordenamento jurídico prescreve a personalidade do ser humano e sua dignidade como tal, e como uma de suas expressões fundamentais, o direito à vida, não há razão para limitar esse direito a uma só etapa do ciclo vital excluindo outra. Tal conclusão teria um fundamento, pois se imporia pelos valores e princípios consagrados na Carta Magna (e, em particular, no art. 72, que recepciona, positiviza, o jusnaturalismo clássico).

(33) Ver sobre el punto, el LANZIANO, Wáshington. op. cit., p. 49 e ss. 
provas" para determinar a identidade das pessoas, independentemente de sua idade, e também, em hipóteses de calamidades, quando praticamente já não resta nada do ser humano, ainda que há muito tempo.

No mesmo sentido, Varoa notou que:

os conhecimentos sobre o aparecimento do novo ser humano estão hoje apoiados solidamente em bases biológicas, embriológicas, genéticas e também médicas, que pertencem ao acervo científico comum. Cada indivíduo tem um começo... que é a concepção ... , pois a genética permitiu saber que o óvulo fecundado possui integralmente a identidade de outro ser ${ }^{(34)}$.

Esta tese é a que tende a prevalecer entre nós ${ }^{(35)}$ e é a que é sustentada pela sentença do Tribunal Constitucional de Chile, segundo se viu.

\section{5.a. Os distintos significados da concepção}

Convém precisar que não existe um significado único do que se entende por concepção, pois mesmo que o núcleo dos distintos modos de entendê-la

(34) VARELA, Juan Alberto. Derecho de familia y genética. Montevideo: FCU, 1990. p. 7-8.

(35) Esta tese que tem hoje um grande número de seguidores e apoios normativos importantes, especialmente o Pacto de San José de Costa Rica, foi sustentada pelo Presidente da República para vetar as disposições da lei que despenalizava o aborto. De acordo com ela as disposições do CC referentes ao concebido, poderiam ser entendidas, como parece o faz Vaz Ferreira (VAZ FERREIRA, Carlos. Tratado de las sucesiones. Montevideo, 1988. t. 1, v. 2, p. 346 e ss.), não como confirmadoras das regras gerais sobre capacidade jurídica, mas no sentido de que estabeleceriam requisitos adicionais à personalidade para sua configuração, como o nascimento e a viabilidade nos termos da lei, que se explicariam pelas necessidades do tráfico jurídico relativo aos direitos patrimoniais. Nesta linha, encontra-se também ORDOQUI, Gustavo. Protección de los derechos del concebido. Revista Uruguaya de Derecho de Familia, t. 5, p. 137 e ss., 1990. Según Sánchez Fontáns (SÁNCHEZ FONTÁNS. Capacidad y legitimación. Montevideo, 1953. p. 3, 17 en nota 12), o concebido não apenas é capaz, para receber por doação ou testamento, como pode ser parte em outros contratos, por exemplo, em um contrato de venda, se fosse necessário vender o bem adquirido, porque corre perigo de se deteriorar ou para pagar uma dívida de herança, e "as normas legais relativas à capacidade no contrato de doação se limitam a confirmar igualmente os princípios gerais" $(10,40)$. Ver também sobre o ponto: AREZO PÍRIZ, Enrique. El comienzo de la personalidad en el derecho positivo Uruguayo. Revista Jurídica Estudiantil, p. 102, 1993; YGLESIAS PEROLO, Arturo. Sobre la personalidad, su inicio y su fin. Revista Uruguaya de Derecho de Familia, n. 10, p. 83 e ss., e na edição atualizada pelo mesmo autor com a colaboração de Díaz Sierra, Ma. Del Carmen. Personas, de Cestau, Saúl D. 4. ed. Montevideo: FCU, 1997. v. 3. Ainda que distinga segundo a natureza dos direitos em jogo e considere que em matéria de direitos patrimoniais a norma dirigente segue sendo o art. 835 do C.C. Ver também también LANZIANO, Wáshington. Derechos humanos. Montevideo, 1998. esp. p. 177 e ss. e especialmente El aborto y el derecho a la vida, cit., p. 112 y ss onde realiza uma extensa e fundada exposição do tema. Ainda que este autor não deixe de reconhecer que a tese da nidação resolve, de modo pragmático, uma pluralidade de problemas, ele se inclina pela tese da concepção, por razões que, em geral, são as mesmas empregadas para fundar o referido veto presidencial. A sentença n. 134/1999, de 28.7.1999, do Tribunal de Apelaciones de Familia de 1er. Turno (caso 13.821 de La Justicia Uruguaya, t. 120, ps. 284 y s.s.) é particularmente interessante porque após considerar as distintas posições em jogo, toma partido pela concepção como momento do surgimento da personalidade. 
resida em considerar que ela coincide com a fecundação do óvulo, não há acordo quanto ao momento do processo de fecundação a considerar, tendo em conta que pode durar várias horas, desde quando começa, com a penetração do espermatozoide na capa externa do óvulo até a singamia, momento em que os cromossomos de ambas as células se fundem, criando um conteúdo genético único, distinto daquele dos componentes materno e paterno. Pareceria então razoável entender que a concepção se produz com a singamia, pois, é nesse momento que surge um novo ser com identidade própria.

O outro problema que se coloca, é o de se a concepção a ser considerada é só a que se verifica no álveo materno (in corpore) ou se também se deve considerar a que se produz fora dele ou in vitro. Este tema está distante de ser meramente teórico, uma vez que tem grandes repercussões práticas, mas não é o caso de analisá-las agora ${ }^{(36)}$.

Ainda quando se pudesse considerar que o problema estivesse resolvido do ponto de vista científico (e vimos que também nele há aspectos discutíveis), não significa que a questão jurídica também o esteja, pois como se nota, a história nos revela que nem sempre as noções de ser humano e pessoa caminharam juntas ${ }^{(37)}$. A meu juízo, entretanto, no momento atual e à luz do art. 72 de nossa Constituição, tais noções são inseparáveis. Dado que todos os elementos que individualizam um novo ser (e que continuarão a fazê-lo ao longo de sua existência e mesmo depois) se encontram presentes desde o momento da concepção (especialmente quando se considera a fase de singamia), seria necessário concluir que o surgimento da personalidade se produz com a fecundação do óvulo.

Existem, por outro lado, várias disposições constitucionais e legais que apoiam esta tese ${ }^{(38)}$ e em particular o faz o chamado Pacto de San José de Costa Rica (Convenção Americana sobre Direitos Humanos) ${ }^{(39)}$ aprovado pela Lei n. 15.737, de 8 de março de 1985, que determinou a consolidação da consideração do momento da concepção, como ponto de surgimento da personalidade ${ }^{(40)}$.

(36) Ver GARCÍA DÍAZ, Fernando. Concepción e inicio del individuo humano. Bioética \& Debat. Disponible en: <http://www.bioetica-debat.org/modules/news/articles> (enviado el 25.9.2007). LANZIANO, Wáshington. El abortoy el derecho a la vida, cit., p. 64 y ss.

(37) Entre outras razões pelas circunstâncias de que estão em jogo noções que pertencem a mundos diversos (o do ser e o do dever ser, o homem e a pessoa, o direito e a moral, a ciência e o direito), como assinala KELSEN, Hans. op. cit., p. 126. As relações entre a moral, a ciência e o direito nem sempre se entendem da mesma maneira, como acentua FERRAJOLI, Luigi. op. cit.

(38) Ver LANZIANO, Wáshington. El aborto y el derecho a la vida, cit., p. 123 e ss.

(39) $\mathrm{O}$ art. 1ำ da Convenção diz que: "Toda pessoa tem direito a que se respeite sua vida. Este direito será protegido pela lei e, em geral, a partir do momento da concepção".

(40) Ver AREZO PÍRIZ, Enrique. op. cit. e ORDOQUI, Gustavo et al. Derecho de familia y genética. Ciclo de conferencias. Ed. Fundación de Cultura Universitaria, 1990. p. 60-61. 


\section{A tese da nidação}

Apesar da conclusão que acaba de ser afirmada, é preciso fazer referência a outra tese, a da nidação, segundo a qual o começo da personalidade se produziria em um momento posterior à concepção, o da nidação do óvulo fecundado ${ }^{(41)}$. Para alguns inclusive, é só então que se pode falar de concepção, já que é nesse momento que a mulher fica grávida ${ }^{(42)}$. Essa teoria tem importantes respaldos de instituições como a Organização Mundial da Saúde (OMS) e o American College of Obstetricians and Gynecologists (ACOG). Um de seus fundamentos centrais é o de que é a que melhor satisfaz as necessidades de certeza e segurança jurídicas, que são indispensáveis para um estado de direito.

Assim, diz Buompadre que "enquanto não se produza a fixação do ovo fecundado na matriz, não se poderia afirmar inequivocamente a existência de uma gestação cuja interrupção seja abortiva. A proteção penal antes da nidação se assentaria em grande parte no imaginário"(43). Assinalou-se também que durante o processo prévio à nidação, o zigoto pode-se dividir (e, em vez de um, ser dois ou três, por exemplo), fundir (dois ou três se juntarem em um) ou pode ser expulso, pelo que ainda não haveria uma expectativa plena e segura de vida individualizada.

A tese da nidação tem pois a vantagem não desdenhável de marcar com razoável precisão o momento em que se produz a gestação e o começo de uma etapa na qual o desenvolvimento normal do feto desembocará em seu nascimento e consequente independência da mãe. Ela permite resolver espinhosos temas como o da fecundação in vitro e o da situação do embrião antes de sua implantação no útero e tem importantes consequências quanto à constitucionalidade de normas que permitam o uso de fármacos e procedimentos que, comprovadamente, não tenham efeito sobre o embrião logo que nidado.

\section{A incidência da aceitação de uma ou outra tese na questão resolvida pela sentença que se comenta}

Antes de considerar qual é a referida incidência deve-se fazer uma breve e sintética, porém, necessária, referência aos efeitos dos fármacos questionados.

(41) Existem discussões também a respeito de onde se produz a nidação. Enquanto que para alguns é indiferente, para outros só se deve considerá-la produzida no endométrio, deixando fora a nidação ectópica (gravidez tubária).

(42) Ver GARCÍA DÍAZ, Fernando. op. cit., n. 3.

(43) BUOMPADRE, Jorge. Derecho penal: parte especial. Buenos Aires: Ed. Mario A. Viera, 2000, t. 1. p. 180-181. 


\section{7.a. Os efeitos comprovados da pílula do dia seguinte}

Em primeiro lugar, deve-se notar que a evidência científica disponível não permite demonstrar com razoável certeza que os fármacos e procedimentos referidos afetam o concebido, impedindo sua implantação. É também evidente, por outra parte, que ainda que não exista a indicada certeza, não é menos certo que há uma possibilidade de que tal situação se produza.

É, portanto, necessário, a meu juízo, concluir que o efeito que tais fármacos e procedimentos produz é uma espécie de perda de uma chance (de implantação, no caso) ${ }^{(44)}$. Assim, caso se constatasse que em determinadas circunstâncias, em que se utilizaram os fármacos questionados, a concepção não culminou na implantação, ainda que não existisse uma demonstração da relação de causalidade entre tal utilização e o indicado resultado, não há dúvida, no estado atual do conhecimento científico do tema, de que ao menos haveria uma possibilidade de que isso ocorresse, pelo que se poderia afirmar que o concebido por efeito de tais fármacos perdera uma chance de implantação.

Em segundo lugar, a evidência científica atual permite afirmar que o levonorgestro não afeta o embrião implantado. A aceitação da tese da concepção ou da nidação tem pois grande importância para a solução do tema. Uma vez que se, como já se afirmou reiteradamente, os fármacos e mecanismos questionados não afetam o embrião implantado, então para quem sustenta a tese da nidação eles não produziriam efeitos abortivos, pois o nascimento da personalidade se verificaria no momento da implantação. As coisas se passam diversamente para os partidários da tese da concepção, pois, como se viu, para alguns existe pelo menos uma possibilidade de que o efeito de tais fármacos e procedimentos seja o de impedir a nidação do óvulo fecundado, o que, nesse marco conceitual, se deveria qualificar como abortivo. Que é precisamente o que sustenta a sentença do Tribunal Constitucional chileno.

\section{7.b. Balanço provisório}

Como um balanço provisório, quanto às teses da concepção e da nidação examinadas e sua incidência no tema analisado, é conveniente fazer algumas precisões.

Em primeiro lugar que, ainda quando do ponto de vista científico pareça claro que o momento que marca o surgimento de um novo ser dotado de

(44) Ver sobre a questão da perda de uma chance como dano indenizável, mas também - e é o caso que mais interessa - sua incidência na prova da relação de causalidade, GAMARRA, Jorge. Responsabilidad civil médica. 2. ed. Montevideo: FCU, 2001. p. 300 e ss. 
individualidade própria é o da concepção (sobretudo se referida à singamia), - legislador, para satisfazer a indispensável necessidade de segurança jurídica, pode fixar outro momento, o da nidação, para regular determinadas situações como a penalização de certas condutas, o que será sem dúvidas admissível para quem sustenta que o direito à vida pode ser regulado mediante uma lei fundada em razões de interesse geral.

Em segundo lugar que, partindo da base da aceitação da tese da concepção, isso não seria suficiente para resolver a questão colocada, pois, apenas se sustenta, custe o que custar, que basta haver uma possibilidade, ainda que remota, de que se impeça a nidação e que não é necessário ter em conta se existem ou não outros direitos em jogo que poderiam ser afetados, se poderá postular, como faz a sentença do Tribunal Constitucional chileno, a inadmissibilidade constitucional de normas que permitam o uso dos fármacos do dia seguinte.

Por minha parte, entendo que (especialmente neste caso) não se pode prescindir de considerar a circunstância de que a questão é suscitada no marco de um conflito entre o direito à vida com outros princípios e direitos. Ponto que será tratado mais adiante.

\section{8. $O$ conflito com outros direitos. $O$ direito prevalente. A ponderação}

Se o problema do direito à vida do embrião fosse colocado de modo isolado, seguramente seria de mais fácil solução, mas ele se encontra em conflito com outros princípios e direitos, como o da liberdade (especialmente a sexual e reprodutiva) da mulher e o direito a uma vida digna e saudável; e com o valor da proteção da vida da mulher numa pluralidade de casos, nos quais, como se sabe, corre sérios riscos, ao buscar o aborto clandestino. Também estão em jogo outros valores e interesses, como os relativos à saúde pública.

Naturalmente, para quem sustenta que o direito à vida (que compreenderia o direito a nascer) é absoluto e prevalente frente a qualquer outro direito, invocar o conflito não passa de uma mera ilustração, pois ele está resolvido de antemão: necessariamente deve prevalecer o direito à vida ${ }^{(45)}$. É o caso do Tribunal Constitucional chileno, que fazendo valer o princípio pro vida sustenta que basta existir uma dúvida de que haja uma possibilidade de que certo fármaco ou procedimento seja abortivo, ainda que não seja provável, para que, quem sustenta que é legítimo empregá-lo, tenha o ônus de demonstrar que ele não tem o indicado efeito ${ }^{(46)}$.

(45) De algum modo se está aplicando a tese do peso específico dos princípios e sua hierarquização. Ver sobre o ponto: Por uma visão crítica da tese da hierarquia dos princípios, FIN-LANGER, Laurence. L'equilibre contractuel. Paris: LGDJ, 2002. p. 556 e ss. e as indicadas obras de Vigo.

(46) Ver p. 6 (II 3, n. 8). 
Diferentemente, para quem pensa que estão em jogo outros valores que se encontram em conflito com o direito à vida e que o grau de ofensa é meramente hipotético, dependendo de fatores, que não só não são suscetíveis de demonstração e também da tese que se considere admissível no ponto do nascimento da personalidade. Estes se inclinarão por uma solução de sinal oposto e sustentarão que, enquanto não exista uma dúvida razoável acerca do efeito abortivo de certos fármacos e procedimentos, deve-se admitir a legitimidade e constitucionalidade das normas que permitem seu uso e, por conseguinte, são aqueles que afirmam a existência desse efeito abortivo quem deve demonstrá-lo, especialmente se uma conduta tipificada como delitiva está envolvida.

Ao que se pode agregar o princípio de legitimidade (legalidade ou constitucionalidade) prima facie das normas ${ }^{(47)}$.

\section{8.a. A solução do conflito mediante a ponderação}

A solução do conflito requer, a meu juízo, a técnica da ponderação(48), que se traduz em fazer um balanço entre as vantagens e inconvenientes que certa normativa tem em relação aos direitos em conflito. Como ensina Ale$x y^{(49)}$, o "núcleo da ponderação é constituído por uma relação que, quando se trata de direitos fundamentais... pode ser descrita como o nexo 'entre a intensidade da intervenção e o peso das razões que a justificam"'. A fórmula seria do tipo "quanto maior... tanto maior", que compreenderia tanto os direitos de defesa como os de proteção e que, segundo o autor alemão, poderia ser assim enunciada: "quanto maior é o grau da não satisfação ou da ofensa a um dos princípios, tanto maior deve ser a importância da satisfação do outro". Para ele, será necessário considerar uma escala que pode ter qualquer número de degraus, com um mínimo de dois (leve e grave). Alexy sugere que ela seja de três níveis: leve, médio e grave, por sua praticidade e por ser a que, a seu juízo, "se adapta bem com o labor cotidiano das instituições e da prática jurídica”(50).

(47) Ver nota 8.

(48) Reconheço de todos os modos que não é fácil se manter, no âmbito desse raciocínio, nesse tipo de problemas como o confessava nosso grande filósofo Vaz Ferreira por ocasião da discussão sobre o aborto no parlamento: "eu não posso argumentar nem discutir as razões sobre nada que afete a vida humana”. VAZ FERREIRA, Carlos. Incidentalmente: algunas cartas, discuersos y notas. Montevideo: Cámara de Representantes de a República Oriental del Uruguay, 1957, t. 18. p. 55.

(49) ALEXY, Robert. Tres escritos sobre los derechos fundamentales y la teoría de los principios, cit., p. 65. A ponderação, que se expõe em termos básicos, coloca vários problemas que naturalmente não é possível considerar neste estudo. Sobre ela existem numerosos opus (alguns dos quais têm um sentido crítico), entre eles deve-se mencionar o substancioso estudo de BARCELLOS, Ana Paula de. Ponderação, racionalidade e atividade jurisdiccional. Rio de Janeiro: Renovar, 2005, onde (ainda que nem sempre compartilhemos suas ideias) existe uma interessante bibliografia sobre o tema e se faz extensa menção à brasileira.

(50) ALEXY, Robert. Tres escritos sobre los derechos fundamentales y la teoría de los principios, cit., p. 65 e ss. 


\section{8.b. A ponderação no caso concreto}

No caso concreto a questão se coloca basicamente nesses termos: em que medida a proteção, a tutela dos direitos da mulher, como a liberdade e, em particular a liberdade sexual, o direito a decidir sobre a procriação e, genericamente, o direito a decidir acerca de seu próprio projeto de vida, assim como as razões de saúde pública, seriam afetadas por uma medida que impedisse o uso de fármacos como o levonorgestro ou o DIU (utilizando essa droga) e se o grau de insatisfação desses direitos e interesses é maior ou menor que o da sua utilidade para tutelar o direito à vida do embrião.

Pois bem, não é questionável que a medida indicada em menor grau que outras mais radicais (como as que penalizam o aborto) afete os referidos direitos, princípios e interesses da mulher e da sociedade. Quanto ao grau da ofensa, ela poderia ser qualificada de média (sem prejuízo que, mais de uma vez, no caso concreto, ela será seguramente alta). Por outro lado, se trata de determinar qual é o grau de satisfação do direito à vida do embrião que a medida importa ou, o que é a outra cara da mesma moeda, que grau de ofensa sofreria esse direito se não se adotasse a medida. Para quem sustenta que a personalidade se adquire com a concepção (entendida como singamia) e considera que há um alto grau de possibilidade de que os fármacos e procedimentos referidos produzam efeitos antinidatoórios, a ofensa será alta. Portanto, a conclusão a que chegarão é a de que, nesse caso, se deverá considerar inaceitável (na espécie, inconstitucional) as normas que permitam seu uso.

Nas antípodas, para quem a personalidade surge com a nidação (e com mais razão ainda para os que afirmam que ela nasce num momento ulterior), não há ofensa ao direito à vida da pessoa e, portanto, não haveria obstáculo constitucional para normas que admitam seu emprego. E numa situação intermediária, de mais difícil solução, se encontra a posição de quem sustenta, como ocorre com a primeira hipótese, que a personalidade surge no momento da concepção, mas que (e nisso reside a diferença com a segunda) entende que não está demonstrado (e nem sequer é provável) que o emprego do levonorgestro, só ou combinado com o etinil-estradiol (método uzpe) ou do DIU (com administração desse tipo de fármacos), possa ter efeitos antinidatórios. Nessa hipótese, o que ocorre, como se notará, é que na ausência de demonstração da existência de nexo causal, entre o uso de tais fármacos e o efeito antinidatório, se poderá falar da perda de uma chance. Para alguns, inclusive, sendo o grau de probabilidade muito pequeno, tal perda de chance será ainda menor.

$\mathrm{Na}$ espécie, portanto, se pode sustentar que o grau de ofensa das normas permissivas sobre o direito à vida do embrião, depois da fecundação e antes da nidação, é de leve à média. Nesse caso, então, ainda que de modo não muito claro, a balança poderia se inclinar para a admissibilidade das normas permissivas dos fármacos e procedimentos questionados. 
Esta é seguramente a tese do Ministério de Saúde Pública uruguaio. Para confirmar, basta notar que: a) publicou um guia para a saúde sexual da mulher, em 2005, no qual se faz específica referência ao levonorgestro, seja só ou combinado com o etinil-estradiol, colocando-os entre os métodos anticonceptivos de emergência, e excluindo especificamente que possam ter efeitos abortivos:

Se pode afirmar que as PAE não alteram o endométrio nem impedem a implantação. Isto foi confirmado por meio de estudos sobre o estado do endométrio em mulheres e fêmeas de animais submetidas às PAE e também porque aproximadamente uma de cada 10 gestações que se espera que ocorra após um coito não protegido em período fértil, ocorre apesar do uso da PAE. Por isso se pode afirmar que: As PAE não interrompem uma gestação estabelecida nem causam um aborto.

Complementarmente, em 3 de março de 2008, esse Ministério (em sua página web) informa que um de seus êxitos importantes foi.

A possibilidade de colocação gratuita do dispositivo intrauterino (DIU) em centros de saúde públicos e privados", pois "põe ao alcance de todas as mulheres do país uma alternativa anticonceptiva. Constitui um passo mais em direção à igualdade de direitos e oportunidades para a mulher e também, a possibilidade de decidir acerca de sua maternidade. O lançamento da campanha para colocação gratuita do DIU (dispositivo intrauterino) constitui um passo mais até a igualdade de direitos e oportunidade, em relação à saúde sexual e reprodutiva das mulheres.

Talvez se possa objetar com a falta de uma referência mais detalhada à informação relativa à posição científica contrária, especialmente considerando-se a situação das pessoas para quem o uso dos fármacos e procedimentos questionados e seus efeitos envolvem questões morais e religiosas (como ocorreria para quem professa a religião católica, já que é por certo amplamente reconhecida a posição da Igreja contrária à chamada pílula do dia seguinte).

\section{A consideração global do tema. Síntese.}

Como síntese, pode-se chegar às seguintes constatações:

a) Em primeiro lugar, não se sabe com certeza se fármacos como o levonorgestro têm um efeito anti-nidatório.

b) A questão do começo da personalidade continua em debate e quem sustenta que ela se inicia com a implantação não deixa de ter importantes razões (notadas, sobretudo, no funcionamento prático desta teoria, como se verificou) e tudo indica que o levonorgestro não tem qualquer incidência sobre o concepto após sua implantação. 
c) Em terceiro lugar, não só não está provado que tal fármaco age impedindo a implantação, mas que sua finalidade (e sua eficácia) é fundamental (e para alguns) exclusivamente, anticonceptiva. $O$ efeito de impedir a concepção, claramente, não é abortivo, já que nesse momento (e nisso não parece razoável qualquer discussão científica), não existe ainda um novo ser, um indivíduo distinto de sua mãe e dos demais.

d) Se as considerações precedentes estão corretas, a questão da perda de uma chance de implantação (que não é, além disso, de maior probabilidade de realização), não parece razoável ser colocada do mesmo modo e com o mesmo alcance que a do aborto, que supõe a privação do direito de nascer, ou, mais cruamente, a eliminação de um ser, ou concepto, que tem todos os elementos necessários para identificá-lo como um ser humano dotado de sua própria identidade genética. Tanto não o é que em países como o nosso em que se penaliza o aborto, se admite a legitimidade do uso dos fármacos e procedimentos questionados.

e) Tal questão se coloca no marco de um conflito entre o direito à vida do concepto e certos direitos da mulher (como o da liberdade sexual e o de decidir sobre a procriação) e da sociedade (como são os interesses da saúde pública).

f) A adequada colocação do problema em análise leva a decidir a questão utilizando, como sucede cada vez em que se encontram em conflito direitos fundamentais e princípios (entendidos segundo diz Alexy, como mandados de otimização), a técnica da ponderação.

g) Finalmente, pode ocorrer que, ainda que recorrendo à ponderação, não se obtenha como resultado uma solução incontroversa do ponto de vista jurídico. O que não é surpreendente, pois, como demonstrou Kelsen, a interpretação de uma norma não conduz sempre a um único resultado. E neste caso, o juiz (como ocorreu no caso estudado), mediante um ato de vontade, elegerá a que considere a melhor solução(51).

\section{REFERÊNCIAS BIBLIOGRÁFICAS}

ABADIE SANTOS, Horacio. La impunidad del aborto consensual. Montevideo: Larre \& Cía, 1935.

ABORTO en debate. Dilemas y desafíos del Uruguay democrático. Disponible en: <www.leyaborto.org/esp/publicaciones/libros.php>.

ALEXY, Robert. El concepto y la validez del derecho. 2. ed. Barcelona: Gedisa, 2004.

(51) É a mesma solução a qual chega ALEXY para o caso de empate, Tres escritos... cit., p. 72. 
Tres escritos sobre los derechos fundamentales y la teoría de los principios. Bogotá: Universidad Externado de Colombia, 2003.

AREZO PÍRIZ, Enrique. El comienzo de la personalidad en el derecho positivo Uruguayo. Revista Jurídica Estudiantil, 1993.

BARCELLOS, Ana Paula de. Ponderação, racionalidade e atividade jurisdiccional. Rio de Janeiro: Renovar, 2005.

BLENGIO, Juan. La autonomía de la voluntad y sus límites: su coordinación con el principio de igualdad. Anuario de Derecho Civil Uruguayo, t. 27, 1997.

BUOMPADRE, Jorge. Derecho penal: parte especial. Buenos Aires: Ed. Mario A. Viera, 2000. t. 1.

CASSINELLI MUÑOZ, H. Protección en el goce de bienes fundamentales y acción de amparo. Revista Colegio de Abogados del Uruguay, t. 36, nov. 1993.

CESTAU, Saúl. D. civil: primer curso. Apuntes de clase, 1966.

DEL CAMPO, Francisco. Personas. Montevideo: Medina, 1962.

DELPIAZZO, Carlos E. Dignidad humana y derecho. Montevideo: Universidad de Montevideo, 2001.

DÍAZ SIERRA, Ma. Del Carmen. Personas, de Cestau, Saúl D. 4. ed. Montevideo: FCU, 1997. v. 3.

DWORKIN, Ronald. Interpretación constitucional. 2. ed. Buenos Aires: Ed. Lexis Nexis; Abeledo-Perrot, 2004. . Los derechos en serio. Barcelona: Ariel, 1984.

FACULTAD de Derecho. Universidade del Chile. Disponible en: <www.derecho. uchile.cl/cej/actulidad/otro/Sentencia_Constitucional\%20Sobre\%20la\%20Pildora\% 20del\%20Dia..>.

FERRAJOLI, Luigi. La questione del embrione tra diritto e morale. Politeia, $\mathrm{n}$. 65, 2002.

FIN-LANGER, Laurence. L'equilibre contractuel. Paris: LGDJ, 2002.

GAMARRA, Jorge. Responsabilidad civil médica. 2. ed. Montevideo: FCU, 2001.

GAMARRA, Jorge; BLENGIO Juan E. Tratado de derecho civil Uruguayo. Montevideo: FCU, 2000. t. 10.

GARCÍA DÍAZ, Fernando. Concepción e inicio del individuo humano. Bioética \& Debat. Disponible en: <http://www.bioetica-debat.org/modules/news/ articles>.

GATTI, Hugo E. Personas. Montevideo: Acali, 1977. t. 1. 
GOROSITO ZULUAGA, Ricardo. El derecho a la vida, su protección constitucional. Revista Uruguaya de Derecho Constitucional y Político, t. 11, n. 62, ago./set. 1994.

KELSEN, Hans. Teoría pura del derecho. 5. ed. Buenos Aires: Eudeba, 1962.

LANZIANO, Wáshington. Derechos humanos. Montevideo, 1998. El aborto y el derecho a la vida. Montevideo: FCU, 2003.

MANZONI RUBIO, Luis B. Constitución y aborto. Revista de Derecho Público, Año 13, n. 26, 2004, p. 81e ss.

ORDOQUI, Gustavo. Protección de los derechos del concebido. Revista Uruguaya de Derecho de Familia, Tomo 5, 1990, p. 137 e ss.

ORDOQUI, Gustavo y otros. Derecho de familia y genética, ciclo de conferencias", Ed. Fundación de Cultura Universitaria, 1990.

QUINTÍN, Alfonsín. Sobre la existencia de las personas en derecho privado internacional. In: Estudios Jurídicos en memoria de Juan José de Amézaga. Montevideo: Facultad de Derecho y Ciencias Sociales, Montevideo, 1958.

RAMÓN REAL, Alberto. Los principios generales de derecho en la Constitución Uruguaya: vigencia de la estimativa iusnaturalista. Montevideo: Ed. Librería Juan A. Peri, 1958.

RISSO FERRAND, Martín. Síntesis de la regulación constitucional de los derechos fundamentales en el Uruguay. Revista de Derecho Constitucional y Político, t. 12, n. 67/71, jun. 1995, mar. 1996.

SÁNCHEZ FONTÁNS. Capacidad y legitimación. Montevideo, 1953.

VAN ROMPAEY, Leslie. Hacía una jurisprudencia principialista. Revista de Derecho de la Universidad Católica, v. 6, 2004.

Reflexiones sobre los principios generales de derecho. Anuario de Derecho Civil Uruguayo, t. 30, año 2000.

VARELA, Juan Alberto. Derecho de familia y genética. Montevideo: FCU, 1990.

VAZ FERREIRA, Carlos. Incidentalmente: algunas cartas, discuersos y notas. Montevideo: Cámara de Representantes de a República Oriental del Uruguay, 1957. t. 18.

. Tratado de las sucesiones. Montevideo, 1988. t. 1, v. 2.

VIGO, Rodolfo. Los principios jurídicos. Buenos Aires: Depalma, 2000.

YGLESIAS PEROLO, Arturo. Sobre la personalidad, su inicio y su fin. Revista Uruguaya de Derecho de Familia, n. 10, 1995. 